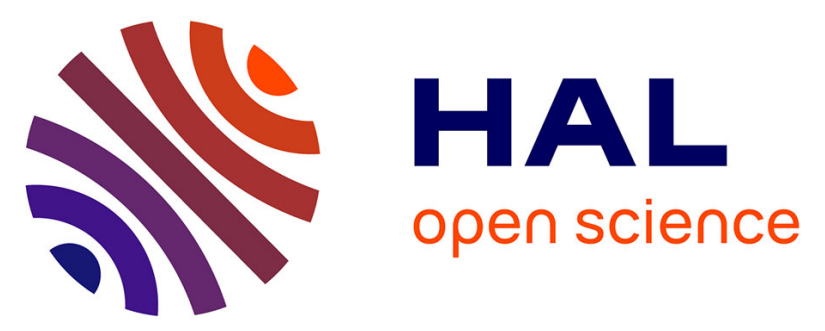

\title{
Influence of soil properties and burial depth on Persian oak (Quercus brantii Lindl.) establishment in different microhabitats resulting from traditional forest practices
}

\author{
M. Heydari, B. Prévosto, H. Reza Naji, A.A. Mehrabi, D. Pothier
}

\section{- To cite this version:}

M. Heydari, B. Prévosto, H. Reza Naji, A.A. Mehrabi, D. Pothier. Influence of soil properties and burial depth on Persian oak (Quercus brantii Lindl.) establishment in different microhabitats resulting from traditional forest practices. European Journal of Forest Research, 2017, 136 (2), pp.287-305. 10.1007/s10342-017-1029-4 . hal-01579219

\section{HAL Id: hal-01579219 \\ https://hal.science/hal-01579219}

Submitted on 30 Aug 2017

HAL is a multi-disciplinary open access archive for the deposit and dissemination of scientific research documents, whether they are published or not. The documents may come from teaching and research institutions in France or abroad, or from public or private research centers.
L'archive ouverte pluridisciplinaire HAL, est destinée au dépôt et à la diffusion de documents scientifiques de niveau recherche, publiés ou non, émanant des établissements d'enseignement et de recherche français ou étrangers, des laboratoires publics ou privés. 
Author-produced version of the article published in European Journal of Forest Research, 136, 2, 2017, 287-305. The original publication is available at https://link.springer.com/article/10.1007/s10342-017-1029-4

DOI: 10.1007/s10342-017-1029-4

Influence of soil properties and burial depth on Persian oak (Quercus brantii Lindl.) establishment in different microhabitats resulting from traditional forest practices

Mehdi Heydari* ${ }^{1}$, Bernard Prévosto ${ }^{2}$, Hamid Reza Naji ${ }^{1}$, Ali Ashraf Mehrabi ${ }^{3}$, David Pothier ${ }^{4}$

${ }^{1}$ Department of Forest Science, Faculty of Agriculture, University of Ilam, Ilam, Iran.

${ }^{2}$ Irstea, UR RECOVER, Ecosystèmes méditerranéens et risques, 3275 Route Cézanne, CS 40061,

F-13612 Aix-en-Provence Cedex 5, France

${ }^{3}$ Department of Plant Breeding, Faculty of Agriculture, University of Ilam, Ilam, Iran

${ }^{4}$ Centre for Forest Research, and Department of Wood and Forest Sciences, Laval University,

Québec, QC G1V 0A6, Canada

* Corresponding author 


\begin{abstract}
In seasonally dry environments such as the Zagros Woodlands (Iran), severe drought stress and lack of appropriate management practices can cause failure of oak afforestation or reforestation. We investigated the effect of soil properties and burial depth on Persian oak (Quercus brantii Lindl.) establishment in different microhabitats resulting from traditional forest practices. Four microhabitats that were based on forest structure were considered for oak acorn seeding: (1) inside old sprout clumps (ISPC); (2) under the canopy of tall trees (UCTT); (3) outside the canopy of tall trees and sprout clumps (OCTS); and (4) near recent stumps or sprout clumps (RSC). Acorns were seeded at two depths ( 2 and $5 \mathrm{~cm}$ ) and seedling survival and growth variables were recorded for 4 years, together with soil chemical and biological attributes. Stepwise discriminant analysis showed that a combination of total soil nitrogen, cation exchange capacity, available phosphorus and potassium, litter depth, microbial quotient, metabolic coefficient, substrate induced respiration and earthworm abundance were the best variables to characterise the microhabitats. With the exception of $\mathrm{pH}$, bulk density and soil texture, these variables were higher in UCTT and ISPC than in the other microhabitats. Seedling emergence and survival were greater at a seed depth of $5 \mathrm{~cm}$ than at $2 \mathrm{~cm}$. Seedling height and shoot, root and leaf biomasses were higher in the UCTT microhabitat compared to the other microhabitats, and correlated positively with soil nutrients contents and most of the soil biological variables but negatively with soil bulk density. This study emphasised the role of microhabitats in creating a "canopy effect" producing favourable physical, chemical and biological soil conditions. In particular, large oak trees form islands of fertility and therefore are of key importance for successful seedling establishment in forests subjected to intense human activities.
\end{abstract}

Keywords: Seeding, soil biological properties, oak sprout clumps, Zagros woodlands 


\section{Introduction}

Oak (Quercus spp.) species are important components of many temperate and Mediterranean forest ecosystems and, as such, provide habitat for a wide variety of organisms (Lindbladh and Foster 2010; Bugalho et al. 2011; Leonardsson et al. 2015). Indeed, in the arid regions surrounding the Mediterranean basin and southwestern Asia, oaks help regulate water supplies, promote soil conservation, mitigate climate change, and generally improve socio-economic conditions of human populations (Marañón 1988; Ghazanfari et al. 2004; Sagheb-Talebi et al. 2004; Salehi et al. 2010; Valipour et al. 2014). Despite their biological and economic importance, the recruitment of oaks is often problematic worldwide ( $\mathrm{Li}$ and Ma 2003; Bobiec et al. 2011). This observation is typically related to acorn predation by insects, and by large and small mammals (Gómez et al. 2003; Espelta et al. 2009; Rodríguez-Estévez et al. 2012). Seedlings can be browsed, adversely affected by competition, or lost to disease (Ragazzi et al. 1995; Costa et al. 2010; Denman et al. 2014) and abiotic stresses (e.g., Pedersen 1998; Thomas et al. 2002; MacDougall et al. 2010; Ramos-Palacios et al. 2014).

As is the case with population declines in many other temperate zone and Mediterranean forests that are experiencing climate change (Loftis and McGee 1993; Abrams 2003; Rodewald 2003; Steinkamp and Hickler 2015; Helama et al. 2016), the lack of recruitment is particularly challenging in the semi-arid temperate oak forests of the Zagros Mountains of western Iran. Even protected areas are affected, suggesting that the presence of oaks is threatened and that particular management measures may be required to maintain these forests. On the other hand, the continuation of certain current management practices (mostly grazing) may exacerbate recruitment failure in the Zagros Mountains (Khosravi et al. 2016).

In seasonally dry environments, severe drought stress can cause high early seedling mortality (Pausas et al. 2004; Rodríguez-Calcerrada et al. 2010), thereby limiting the overall success of restoration plans. Recruitment failure may result from a lack of suitable safe sites for germination and growth (Rolo et al. 2013). Direct seeding has been proposed as a time- and cost-effective method of maintaining forest composition in diverse ecosystems (Woods and Elliott 2004; Dey et al. 2008). The effectiveness of this 
method can be further modified by establishing more favourable microhabitat conditions. The latter can be created through judicious application of management practices that alter light regimes, as well as soil physical, chemical and biological properties (Strandberg et al. 2005; Pereira et al. 2007; Patrick et al. 2015). These changes can positively influence the growth and physiology of seedlings by modifying both above- and belowground conditions.

In the case of belowground conditions, the emergence, establishment and early growth of seedlings is affected by various physico-chemical properties, including soil water content (Shankar 2006), nutrient availability (Roberts et al. 2005), organic matter thickness (Lafleur et al. 2015), and soil compaction (Jordan et al. 2003), which in turn affect soil biological characteristics (Closa and Goicoechea 2010). In addition, seedlings that are established near canopy trees can benefit from different communities of root symbionts and, thus, increase nutrient uptake compared with seedlings that have established in openings (Simard and Durall 2004). Despite various studies examining the relationships between regeneration and soil physico-chemical properties (Kabrick et al. 2005; Hattori et al. 2013), our understanding is still limited regarding the interplay between these factors (Dickie et al. 2007). The influence of many biological attributes of the soil on seedling establishment has still been poorly studied, although they play a major role in forest ecosystem functions (Selosse et al. 2006).

For example, soil respiration is an important component of forest $\mathrm{C}$ balance, accounting for $60-80 \%$ of total ecosystem respiration and significantly affecting inter-annual variability of net ecosystem productivity, particularly in Mediterranean forest ecosystems (Tedeschi et al. 2006), which are particularly sensitive to drought (Reichstein et al. 2002). Soil respiration reflects not only the activity of plant roots, mycorrhizas, and microbial decomposers, all of which are potentially important to plant growth (Ryan and Low 2005), but also the capacity of the soil to support the biota and biogeochemical processes that they drive, including decomposition, together with soil organic matter quality, quantity and accretion. Yet soil respiration has been never related to seedling establishment, to our knowledge. Other biological properties such as nitrogen availability, carbon availability and litter decomposition have been proposed as suitable indicators of forest 
ecosystem conditions and biological indices of soil quality (Knoepp et al. 2000). Rawnsley (2008) noted that changes in microbial activities or populations can quickly reflect changes in soil chemical and physical properties and can thus be considered as an indicator of impending soil disturbance.

With regard to aboveground conditions, increased solar radiation has been found to have positive effects on regeneration development in canopy gaps (Ashton and Larson 1996; Li and Ma 2003), whereas other studies noted that oak acorn germination and seedling establishment can be facilitated under a forest canopy or nurse shrub cover, especially in arid regions (Bran et al. 1990; Bernhardt and Swiecki 1997; Broncano et al. 1998; Gómez-Aparicio et al. 2003; Rolo et al. 2013; Caldeira et al. 2014). This is the case for Holm oak (Quercus ilex L.) in western Mediterranean forests, where seedling survival was increased under a canopy (Espelta et al. 1995; Puerta-Piñero et al. 2007). In mesic temperate forest ecosystems, the underplanting of a mixed canopy shelterwood system can potentially benefit red oak (Q. rubra L.) and bur oak (Q. macrocarpa Michaux) seedling establishment and growth, (Truax et al. 2000).

In addition to the effects of prevailing below- and aboveground conditions in microhabitats, sowing depth can also influence regeneration establishment as shown by many previous studies (Tietje et al. 1991; Fuchs et al. 2000; Li and Ma 2003; Jalali et al. 2007; Fan et al. 2014).

In this study, we investigate how modification of soil properties by various microhabitat conditions that were created by traditionally coppicing operations can affect Persian oak (Quercus brantii Lindl.) seedling establishment. We focused on the effects of soil attributes and seed burial depth because they were less frequently studied compared to the effects of aboveground conditions. The results from this study can help adjust management strategies to maintain the abundance of Persian oak in areas that are subjected to semi-arid conditions. 


\section{Materials and methods}

\section{Study area}

The study area is part of the Zagros woodland ecosystem, which ranges from northwest to southeast Iran, and is classified as a semi-arid temperate forest (Sagheb-Talebi et al. 2004). These woodlands are located in the Dalab region of Ilam Province (Fig. 1). According to the classification system of de Martonne (1925), the climate of this region is Mediterranean, with annual precipitation of $590 \mathrm{~mm}$ and annual mean temperature of $17{ }^{\circ} \mathrm{C}$. Elevation of the study area ranges from 1100 to $1300 \mathrm{~m}$ and is characterised by a generally flat topography. The dominant soils in the study area are Mollisols (Soil Survey Staff 2014). The soil is calcareous, rich in organic matter with a clay loamy texture and mean depth of $30-40 \mathrm{~cm}$.

The dominant canopy species in these forests is Persian oak (Quercus brantii Lindl.), also known as Brant's oak, which is widely distributed across western Asia and the Middle East (Turkey, Iraq, Syria and Lebanon) (Pourreza et al. 2014). Persian oak covers more than $90 \%$ of the study area with individuals originating either from seed or from coppicing. Seed-origin trees are considered to be the most desired and valuable source of propagules from an ecological perspective (e.g., soil protection and stability), while coppicing frequently results from the imposition of natural disturbance, such as windthrows (Ghazanfari et al. 2004) or, more usually, originates from anthropogenic disturbance that may be incurred by traditional management practices (Salehi et al. 2010; Khosravi et al. 2016). Indeed, trees are frequently cut during land use conversion to agriculture and animal pastures, and for meeting fuelwood demands (Moreno et al. 2007; Salehi et al. 2010). In recent decades, grazing has been controlled by excluding livestock from most afforested areas. The coppice form of these forests alters the primary regeneration pathway, thereby reducing the opportunities for regeneration establishment by seed (Pourreza et al. 2014). Due to a change in national policy that was adopted in 1963, private ownership shifted to public ownership and state forest management. However, traditional practices and conventional ownership have continued since then. One of the most obvious effects of this management is an increase in the percent cover of coppiced stands and, consequently, a decrease in natural seed regeneration (Valipour et al. 2014). 


\section{Experimental design}

Within the study area, we established five $500 \mathrm{~m}$-long parallel transects, which were spaced $200 \mathrm{~m}$ apart. Along these transects, we randomly selected seeding locations that corresponded to four forest conditions (referred to as "microhabitats"), which resulted from traditional coppicing practices. The microhabitats were: (1) inside old sprout clumps that were taller than $3 \mathrm{~m}$ (ISPC), which is a sign of a previous disturbance; (2) under the canopy of tall trees (UCTT; mean tree height $>5 \mathrm{~m}$ ); (3) outside the canopy of tall trees and sprout clumps (OCTS); and (4) adjacent to (1-2 m) recent stumps or sprout clumps, with a mean height less than 1.5 $\mathrm{m}$ (RSC), which is a sign of recent disturbance (Fig. 2). Stand characteristics of these microhabitats are summarised in Table 1.

At each planting location (10 locations per microhabitat $\mathrm{x} 4$ microhabitats $=40), 5$ oak acorns were manually sown in adjacent separate holes at depths of 2 and $5 \mathrm{~cm}$, respectively, in December 2010 (i.e., 40 locations $\times 2$ depths $\times 5$ acorns $=400$ acorns). In the ISPC microhabitat, oak acorns were sown in the centre of a sprout clump, adjacent (1-2 m) to parent trees that were present in the UCTT microhabitat.

All acorns that were to be sown were collected in autumn 2010 from naturally established elite trees that were located within the experimental area. After eliminating non-viable acorns by careful visual screening, the seeds were selected using the same morphological characteristics (mean seed length $\pm \mathrm{SE}$ of $3.81 \pm 0.11 \mathrm{~cm}$, seed width of $1.62 \pm 0.18 \mathrm{~cm}$ and seed mass of $6.63 \pm 1.20 \mathrm{~g}$ ) to control seed mass, which can influence seedling emergence and early development (e.g., Quero et al. 2007; Ramirez-Valiente et al. 2009; PerezRamos et al. 2010). Germination of $94 \%$ was observed from a test using 100 seeds that were sown in sterile sand under controlled conditions of temperature and humidity. The acorns were randomly assigned among microhabitats. After planting, the study area was protected by forest rangers to avoid disturbance incurred by local inhabitants. Persian squirrels (Sciurus anomalus) and wild boars (Sus scrofa) are major acorn consumers in Zagros forests (Pourhashemi et al. 2012) and may also affect the success of seedling establishment through herbivory. Although the proximity of a main road helped repel squirrels and wild boars from the study area 
(as reported by local inhabitants and forest wardens), we also applied the additional measures before and during the study: 1) acorns were gathered from the seeding areas and dispersed to adjacent regions as a means of decreasing habitat quality for seed predators; 2) to deter predators, we applied capsaicin, which is a natural repellent that is obtained from chili peppers (Nolte and Barnett 2000); and 3) we constructed an exclosure fence around seeding plots. During the four years following acorn planting, all naturally fallen seeds were removed from the seeding areas to maintain uniform conditions. We did not detect any predation by rodents, wild boars or other herbivores over the course of the experiment.

\section{Seedling measurements}

The number of living seedlings was recorded annually in May 2011, 2012, 2013 and 2014. At the end of the experiment (May 2014), the remaining alive seedlings were measured (stem diameter at root collar and height) and carefully excavated. Seedling extraction entailed digging a $60 \mathrm{~cm}$ deep trench at a distance of 20 $\mathrm{cm}$ around each individual to avoid damaging the root systems, after which the entire seedling was carefully removed (Tsakaldimi et al. 2009). For each seedling, we measured total leaf area (CI-203 Handheld Laser Leaf Area Meter, CID Bio-Science, Inc., Camas, WA, USA) prior to determining the oven-dry biomass (70 ${ }^{\circ} \mathrm{C}$ for $120 \mathrm{~h}$ ) of roots, stem and leaves.

\section{Soil sampling and analysis}

Ten composite soil samples were collected in May 2010 for each microhabitat. The bulk samples consisted of material that was collected at four randomly selected locations around each planted seed using the uppermost $25 \mathrm{~cm}$ of the soil. Soils were sieved (2-mm mesh) to remove roots and debris prior to laboratory analyses and divided into two subsamples. The first subsample was air-dried for measuring physico-chemical properties. Additional undisturbed soil cores were collected for the determination of bulk density (BD) in the $0-15 \mathrm{~cm}$ mineral layer (Blake and Hartge 1986). Soil moisture content (water mass/soil dry mass) was determined gravimetrically (oven-drying at $105{ }^{\circ} \mathrm{C}$ for $24 \mathrm{~h}$; Famiglietti et al. 1998). Soil organic carbon (SOC) was 
measured by dichromate oxidation using the Walkley-Black method (Nelson and Sommers 1982). Soil pH was measured electrometrically (in $\mathrm{H}_{2} \mathrm{O}, 2: 1 \mathrm{v} / \mathrm{m}$ ) while electrical conductivity $(\mathrm{EC}$ ) was measured with a conductivity probe in filtered extracts (Kalra and Maynard 1991). Soil cation exchange capacity (CEC) was determined following extraction in buffered sodium acetate (NaOAc, at $\mathrm{pH}$ 8.2; Sumner and Miller 1996). Total $\mathrm{N}$ was determined by Kjeldahl digestion (Bremner 1996). Available phosphorus, as ortho- $\mathrm{PO}_{4}^{-2}$, was determined using the method of Bray and Kurtz (1945). Available potassium was determined following ammonium acetate $(\mathrm{pH} 7)$ extraction and quantified by flame photometry (Black 1986).

The second bulk subsample was maintained at field moisture and stored at $4{ }^{\circ} \mathrm{C}$ for subsequent measurements of soil microbial activity. Microbial biomass carbon (MBC) was measured by determining the organic carbon in chloroform-fumigated and non-fumigated samples by dichromate oxidation, as described by Vance et al. (1987). Soil $\mathrm{MBC}$ was then estimated from the equation: $\mathrm{MBC}=2.64 \mathrm{E}_{\mathrm{C}}$ (Vance et al. 1987), where $\mathrm{E}_{\mathrm{C}}$ is the difference in carbon that was determined in $0.5 \mathrm{M} \mathrm{K}_{2} \mathrm{SO}_{4}$ extracts of fumigated and non-fumigated soils, both of which are expressed as $\mu \mathrm{g} \mathrm{C} \mathrm{g}^{-1}$ oven-dry soil. The microbial quotient (qMic) was calculated as the MBC: SOC ratio (Sparling 1992). Microbial biomass nitrogen (MBN) was determined in the same $\mathrm{K}_{2} \mathrm{SO}_{4}$ extracts, as total Kjeldahl nitrogen (TKN, Brookes et al. 1985). The flush of total $\mathrm{N}\left(\mathrm{K}_{2} \mathrm{SO}_{4}\right.$ extractable- $\mathrm{N}$ from fumigated minus non-fumigated soil) was divided by a $\mathrm{K}_{\mathrm{N}}$ value (fraction of biomass $\mathrm{N}$ extracted after $\mathrm{CHCl}_{3}$ fumigation) of 0.54 (Brookes et al. 1985).

Soil basal respiration (BR) was determined by trapping (in $1 \mathrm{M} \mathrm{NaOH}$ traps) and quantifying $\mathrm{CO}_{2}$ that was emitted from soil samples over a five-day period (Alef and Nannipieri 1995). Substrate-induced respiration (SIR) was determined using glucose $(1 \%)$ as the substrate and the evolved $\mathrm{CO}_{2}$ was measured after $8 \mathrm{~h}$ incubation. Evolved $\mathrm{CO}_{2}$ was adsorbed in $1 \mathrm{M} \mathrm{NaOH}$ and measured by $0.1 \mathrm{M} \mathrm{HCI}$ titration (Anderson and Domsch 1978). A soil microbial metabolic quotient $\left(\mathrm{qCO}_{2}-\mathrm{C} / \mathrm{MBC}\right)$ was calculated as the $\mathrm{CO}_{2}-\mathrm{C}$ evolution per unit MBC per unit time (Anderson and Domsch 1993). 
Because earthworms were found to be useful indicators of forest management regimes (Heydari et al. 2014), earthworms were hand-collected around each planting plot, by sampling an area $50 \times 50 \mathrm{~cm}$ to a depth of 20 $\mathrm{cm}$. Earthworm abundance was calculated by determining the number of individuals per unit surface area $\left(\mathrm{m}^{2}\right)$.

\section{Statistical analysis}

Discriminant function analysis (DFA) was used to find linear combinations of the edaphic biological variables that best separated the microhabitats (Rencher 2003; Pourreza et al. 2014). Wilks' lambda statistic was used as a selection method for stepwise discriminant analysis to choose the variables that were entered in the equation. At each step, the variable that minimised the overall Wilks' lambda statistic was entered. Entry and removal of variables was accomplished using tests of the associated $F$-statistics. Then, a matrix of pairwise $F$ ratios for each pair of microhabitats was used according to the selected variables after each step. Scores were calculated for each discriminant function (DF), and visualised by plotting DF2 against DF1. The associated classification matrix was used to determine the predictive accuracy of the discriminant functions.

Effects of microhabitats (ISPC, UCTT, RSC and OCTS) on each of the soil properties (chemical, physical and microbiological variables) were determined using individual one-way analyses of variance (ANOVA). The effects of microhabitats, seeding depth and their interaction on seedling emergence percentage, height, and biomass components (leaf, stem, root, total aerial biomass, shoot/root ratio) were tested using general linear models (GLM). In addition, the effect of time (year) was tested for seedling survival.

Prior to the analyses, the variables were transformed when necessary to satisfy assumptions of normality and homoscedasticity of residuals. Post-hoc Duncan's tests were used to separate microhabitat means for the same seeding depth. Independent $t$-tests were used to detect significant differences in seedling characteristics between the two depths for each microhabitat. Pearson product-moment correlations $(r)$ explored the relationships between seedling characteristics and soil properties. With respect to the latter properties, only 
soil variables that were most likely to separate microhabitats, based on discriminant analysis, were included in the correlation analyses. All analyses were conducted in SAS (SAS Institute Inc., Cary, NC).

\section{Results}

\section{Soil physico-chemical properties}

Among the soil properties, mean values for SOC, EC, CEC, TKN, P and K were highest in UCTT, which was followed by ISPC, OCTS and RSC in decreasing order (Table 2). Bulk pH varied little among microhabitats, although they formed two groups that could be ordered: OCTS $=$ RSC $>$ ISPC $=$ UCTT. Ordering of means for gravimetric water content among microhabitats was similar to soil $\mathrm{pH}$ : OCTS > ISPC $=$ RSC > UCTT. Bulk density was the lowest in UCTT, which was followed by ISPC, OCTS, and RSC in increasing order. Litter depth was greatest in UCTT and lowest in RSC (Table 2), mirrored the trend observed for soil bulk density. Clay content differed significantly between UCTT and the other microhabitats, whereas silt and sand contents did not differ among microhabitats.

\section{Soil biological variables}

For the biological variables (Table 3), means of MBC, MBN, BR, SIR, qMic and earthworm abundance were significantly higher in UCTT than in ISPC (14-29 \% higher), higher in ISPC compared to OCTS (11-50 \%), and higher in OCTS compared to RSC (12-29\%). With the exception of qMic, mean values in the last two microhabitats were not different. The metabolic coefficient $\left(\mathrm{qCO}_{2}\right)$ was similar between OCTS and RSC (17.51 and 17.31, respectively), but were significantly higher than UCTT and ISPC (15.50 and 13.32, respectively).

\section{Discriminant function analysis}

Stepwise discriminant analysis reveal that a combination of TKN, CEC, P, K, litter depth, qMic, $\mathrm{qCO}_{2}$, SIR and earthworm abundance best separated microhabitats (Table 4). Examination of the pairwise $F$-ratio 
matrices for each pair of microhabitats showed that microhabitats were significantly separated at step 1 , except for RSC from OCTS. At subsequent steps (step 2 onwards), all microhabitats were significantly separated. Steps 3 and 4 reproduced the same results as step 2. According to the selected variables, three significant functions were obtained with respective eigenvalues of $\left(\lambda_{1}=\right) 7.19,\left(\lambda_{2}=\right) 3.24$ and $\left(\lambda_{3}=\right) 0.36$, which explained $79.1 \%, 39.6 \%$ and $8.9 \%$ of the total variance, respectively. According to the standardised coefficients of each variable, TKN (0.333), CEC (0.436), P (0.396), K (0.423), litter depth (0.389), qMic (0.455), earthworm abundance (0.445) and SIR (0.349) in function 1, versus CEC (-0.325), SIR (-0.647), qMic (-0.698), $\mathrm{qCO}_{2}(0.422)$ and earthworm abundance (-0.615) in function 2, were best able to separate microhabitats (Table 4).

Microhabitats ISPC and UCTT were effectively separated from the others along DF1, whereas the microhabitats RSC, OCTS and UCTT could be separated along DF2 (Fig. 3). OCTS and RSC microhabitats were close to one another in the discriminant ordination, suggesting that they were the most similar (Fig. 3). Stepwise discriminant analysis indicated that $82.5 \%$ of the four original microhabitat groupings could be classified correctly according to the microbial predictor variables. Respective microhabitat classification accuracies (Table 5) were $100 \%$ (UCTT), $80 \%$ (ISPC), $80 \%$ (RSC) and $70 \%$ (OCTS).

\section{Seedling characteristics}

The percentage of surviving seedlings was significantly affected by microhabitats, time-since-seeding, seeding depth, and the microhabitat by depth interaction (Table 6). All other interactions did not affect seedling survival. Across microhabitats and at both depths, seedling survival percentage decreased from 2011 to 2014 (Figs. 4a, b). For the last year (2014), highest seedling survival was always observed in UCTT ( $2 \mathrm{~cm}$ depth: $60 \%, 5 \mathrm{~cm}: 70 \%)$ and was lowest in RSC ( 10\%). However, seedling survival in OCTS was as low as in RSC for a seeding depth of $2 \mathrm{~cm}$ (Fig. 4a), whereas higher survivals were recorded in OCTS compared to RSC at a depth of $5 \mathrm{~cm}$ (Fig. 4b). Within each microhabitat, mean seedling survival percentages were higher for deep compared to shallow soil burial $(5 \mathrm{~cm}$ vs $2 \mathrm{~cm}$ ) in OCTS for all years and in ISPC for 2011 
only (Fig. 5). Seedling height, total leaf area, leaf dry biomass, root dry biomass, stem dry biomass and total aerial dry biomass responses were significantly affected by microhabitats, whereas root-collar diameter and shoot/root ratio remained unaffected (Table 7). All variables were similarly not affected, either by the seeding depth or by the microhabitat by seeding depth interaction. Except for the shoot/root ratio, all seedling characteristics were significantly higher in UCTT compared to the other microhabitats, which did not differ (Fig. 6).

\section{Relationships between seedling characteristics and soil properties}

Correlations between seedling characteristics (including emergence, survival, dimensions and biomass) and soil properties showed that soil moisture and soil attributes that are important to plant nutrition $(\mathrm{P}$ and $\mathrm{N}$ contents, soil organic content, CEC) positively influenced seedling characteristics, except for stem diameter and the shoot/root ratio (Appendix 1). The same trend was observed for soil microbial variables, although more significant correlations were detected under the $5-\mathrm{cm}$ rather than the 2-cm burial treatments. Increasing bulk density negatively affected several seedling attributes, particularly under the $5 \mathrm{~cm}$ seeding depth treatment. Lastly, we did not detect any effect of soil texture on seedling performance.

\section{Discussion}

\section{Microhabitats and soil chemical and physical properties}

Our results indicated that SOC, EC, CEC, available P, TKN and K, water content, clay percentage, and litter depth were highest under the canopy of tall trees (UCTT), intermediate inside old sprout clumps (ISPC), and lowest in recent sprout clumps (RSC) and outside canopy (OCTS). These findings are largely explained by greater quantities of litter and other debris under seed-origin mature oak trees, which have larger and denser crowns than those of trees that originated from coppicing (ISPC), while litter accumulation was limited considerably when canopy cover is sparse (RSC) or absent (OCTS). Accumulation of litter leads to higher 
soil organic matter content, which further modifies nutrient availability (Sayer 2006). Indeed, DelgadoBaquerizo et al. (2013) found that high organic-C concentrations accumulate under tussock grasses, forming "islands of fertility" (sensu Schlesinger et al. 1990, 1996; Whitford et al. 1997; Schade and Hobbie 2005; Allegrazza et al. 2016) in arid Mediterranean ecosystems. Islands of fertility extend to many arid zone shrub and tree species, including blue oak (Q. douglasii Hook. \& Am.) woodlands (Dahlgren et al. 1997, 2003). Amelioration of moisture and temperature regimes by developing fertility islands results in more stable microclimates (Allegrazza et al. 2016), decomposer communities and decomposition processes, which generally result in higher $\mathrm{N}$ and $\mathrm{P}$ availabilities. This agrees with positive relationships that have been found between tree proximity and soil fertility (Amézquita et al. 2005; Moreno and Obrador 2007; Howlett et al. 2011). Improvement in soil properties with increasing canopy cover (from OCTS to UCTT) was also observed by Camping et al. (2002), who recorded higher organic carbon, nitrogen and phosphorus levels in soils under a blue oak canopy than in adjacent treeless soils. Similarly, Hailu et al. (2002) reported higher CEC values beneath the crowns of birbira (Millettia ferruginea) than in open field conditions, which was due to greater surface accumulations of organic matter. Organic matter is able to retain base cations for plant use while reducing soil leaching, thereby further increasing CEC. Like organic matter, clay content increases CEC values because both have a large number of negative charges on their surfaces, which attract and hold cations (Tomašić et al. 2013).

Soil pH significantly decreased in both UCTT and ISPC compared with OCTS and RSC. Davenport et al. (1996) observed lower $\mathrm{pH}$ values in the soil under piñon-juniper canopy (Pinus edulis-Juniperus monosperma), when compared to the soils in the intercanopy spaces. This response is likely associated with the decay of plant residues and subsequent production of organic acids beneath the canopy, which results in reduced soil pH. In addition, Augusto et al. (2002) proposed that lower soil $\mathrm{pH}$ beneath a tree canopy was related to higher anion concentrations in soil solution, higher quantities of acids reaching the soil from atmospheric deposition or litterfall (Matzner and Ulrich 1983), a higher degree of protonation of stabilised soil acids (Augusto et al. 2003), and a higher strength of soil acids (Strobel et al. 1999). 
Higher soil electrical conductivity that was observed under the oak canopy (UCTT and ISPC) is consistent with the findings of Jahanbin et al. (2013). These authors measured larger quantities of organic acids under the canopy of common myrtle (Myrtus communis L.) compared to open areas, the result of organic matter decay leading to the dissolution of minerals and ion release, which in turn significantly increased soil EC.

Microhabitats also influenced soil physical properties. Clay concentration was highest in UCTT, likely because of large accumulations of detrital material that retarded the transport and erosion of fine particles by water and wind, a result that was also found by Shukla et al. (2006) in semi-arid woodlands in New Mexico, USA. In the present study, greater quantities of clay and organic matter content increased soil water-holding capacity (Heydari et al. 2013) in UCTT. Also, well-developed canopy covers can influence many abiotic variables in the understorey. For one, reduced irradiance under the canopy results in a cooler environment compared to open areas, while interception of convective and radiative heat loss by the canopy results in a warmer understorey during the night (Jacobs et al. 1994; Niinemets and Valladares 2004). Evapotranspirative demand is therefore reduced, which is typically associated with increased in soil moisture content (Bullock 2000, Monnier et al. 2012; Leiva et al. 2015). These changes have important implications for carbon gain and plant development (Sellin et al. 2010).

Bulk density was lower in UCTT and ISPC, a result that could be explained by accumulation of litter and other debris under tree canopies, which can reduce mineral soil compaction and crusting caused by raindrop impaction (Shukla et al. 2006), while increasing organic matter content in the soil. Conversely, a decrease in soil organic matter increases instability of soil aggregates, which generally results in increased bulk density (Camping et al. 2002; Seymour and Tecle 2004). Accordingly, Tate et al. (2004) showed a canopy cover composed of woody species reduced surface soil bulk density, thereby improving soil quality in a California savannah including blue oak and interior live oak (Q. wislizenii A. DC.). 


\section{Soil biological variables}

Mean values of MBC, MBN, BR, SIR, qMic and earthworms were higher in UCTT than in ISPC, which in turn were higher than in OCTS and RSC (Table 3). Microbial respiration and microbial activity depend upon the quality and quantity of substrate (Cisneros-Dozal et al. 2006; Schuur and Trumbore 2006). Further, microbial physiological profiles, which indicate the range and level of carbon substrate utilisation, show higher activities under a canopy than in open areas, as determined by Classen et al. (2003) from studies conducted in woodland soils of the arid southwestern United States. In addition, microbial activity is affected by variation in temperature, moisture, and other soil physical and chemical properties (Classen et al. 2003; Borken et al. 2006; McCarthy and Brown 2006), all of which are modified by the presence of a canopy. Because the combined effect of tree canopy cover and litter accumulation can moderate fluctuations in soil temperature and moisture, a reduction in canopy cover can decrease soil microbial activities (McCarthy and Brown 2006). This may explain the lower microbial activity that was measured in RSC and OCTS microhabitats compared to UCTT and ISPC. Given that soil organic carbon provides favourable conditions for microorganism activity, soil microbial biomass carbon and nitrogen also increase with increasing soil organic carbon (Ebrahimzad et al. 2013). Tree harvesting and mortality change both litter quality and quantity, together with inputs of $\mathrm{C}$ substrates, nutrient leaching and microclimate, which correspond to conditions found in RSC and OCTS. These changes can adversely affect the activities of the soil biota (Brookes et al. 1990; Marshall 2000; Hannam et al. 2005). The increase of earthworm abundance in UCTT and ISPC is consistent with Salehi et al. (2013), who reported greater earthworm abundances in soils with higher organic matter contents in northern Iran. Density of earthworms (particularly, anecic and epigeic species; Bouché 1977) was strongly dependent upon litter quantity, one of their principal food sources (Sayer 2006). Earthworms and other macro-invertebrates can accelerate litter disappearance through mixing and comminution of leaves (Schädler and Brandl 2005), and further processing of the fine particulate organic matter during gut passage. Their feeding and burrowing increases C-mineralization and microbial biomass, and alters microbial community structure and activity (Saetre 1998; Parkin and Berry 1999; McLean and 
Parkinson 2000; Gómez-Brandón et al. 2011). Thus, higher microbial activity that was measured in UCTT was likely related to increased earthworm abundance.

In our study, $\mathrm{qCO}_{2}$ was higher in RSC and OCTS, indicating possible disturbance of microbial metabolism that was induced by changes in the quantity and quality of available substrates. Pignataro et al. (2012) likewise reported higher $\mathrm{qCO}_{2}$ levels in 3-year-old coppice compared to 50-year-old coppice. Under stress that is induced by management practices, a high value of the metabolic quotient can reflect decreased microbial efficiency in utilising available resources (Sparling et al. 1998); therefore, soil microbes with a high $\mathrm{qCO}_{2}$ are inefficient, diverting a large proportion of acquired $\mathrm{C}$ to maintenance requirements rather than to biosynthesis (Dilly and Nannipieri 1998). Similarly, Zeng et al. (2009) reported negative relationships between metabolic quotient and values of soil organic carbon and MBC after planting Mongolian pine (Pinus sylvestris var. mongolica).

Discriminant analysis differentiated the four sampled microhabitats based on biological, physical and chemical soil variables. A combination of TKN, CEC, $\mathrm{P}, \mathrm{K}$, litter depth, $\mathrm{qMic}, \mathrm{qCO}_{2}$, SIR and earthworm abundance appropriately separated microhabitats. The short distance between OCTS and RSC, and between UCTT and ISPC in discriminant ordination space, suggests that these two combinations of microhabitats were very similar in terms of their soil characteristics. The most visible attribute that differentiated these two combinations of microhabitats was the presence or absence of an oak tree canopy, which was recognised as a significant factor affecting diverse soil properties in many previous studies (Classen et al. 2003; RodríguezCalcerrada et al. 2011; Simón et al. 2013).

\section{Seedling characteristics}

We measured lower seedling emergence and survival at a seeding depth of $2 \mathrm{~cm}$ compared to $5 \mathrm{~cm}$ for the different forest microhabitats, a result that was consistent with previous studies (Kollmann and Schill 1996; Fuchs et al. 2000; Li and Ma 2003; Fan et al. 2014). In these studies, acorn germination and early seedling development were improved with deeper rather than shallower burial depths as a result of the greater 
insulation that was provided by the thicker soil layer which reduced acorn moisture loss and predation. This issue is particularly important in the Zagros oak woodlands, which are characterised by frequent heatwaves and drought events during the summers. Jalali et al. (2007) also noted that maximum seedling emergence of chestnut-leafed oak (Q. castaneifolia) occurred at a seeding depth of $5 \mathrm{~cm}$ in the Caspian forests of northern Iran, compared to seedling emergence following acorn burial at 2 or $15 \mathrm{~cm}$. In contrast to our results, these authors noted that seedling height was not influenced by canopy cover. However, their study was conducted under more temperate and humid conditions. Indeed, we found that at both seeding depths, seedling emergence, survival and growth (height, and the biomass of each seedling compartment) were higher under full tree cover (UCTT) compared to the three other microhabitats that we studied. Seedling survival gradually decreased over time, which can be explained by the occurrence of summer droughts. It should be noted that no particular severe dry events had occurred during the experiment (2011-2014). Therefore, observations over a longer time period are required to determine whether seedling mortality would increase during "dry" years. Indeed, competition from adult trees for soil water may become more intense during dry years and could adversely affect seedling survival in the different microhabitats. Yet, limitation of herb development (not considered in this study) under the tree canopy could indirectly facilitate seedling survival (e.g., Caldeira et al. 2014) compared to open areas.

Light availability, air temperature and humidity, and soil moisture and nutrients are important factors that determine seedling recruitment and growth (Nambiar and Sands 1993; Baskin and Baskin 1998). In Mediterranean environments, these abiotic conditions were improved by the presence of a moderate canopy cover with positive effects on the survival rate of oak seedlings compared to open areas (Broncano et al. 1998; Gómez-Aparicio et al. 2005; Puerta-Piñero et al. 2007; Ibáñez et al. 2015). Our results showed higher soil fertility in UPTC compared to the other microhabitats, together with likely amelioration of aboveground climatic conditions (although this was not measured in this study). As previously indicated, greater quantities of litter and detritus beneath a canopy cover can add $\mathrm{N}$ and $\mathrm{C}$ to the soil, which leads to positive effects on soil structure, biological activity, aggregation, porosity, and infiltration rate that accompany decreases in soil 
bulk density (Shukla et al. 2006; Pereira et al. 2007; Shvaleva et al. 2014; Lafleur et al. 2015; Patrick et al. 2015). These changes can improve the growth and physiology of seedlings (Dickie et al. 2007). Previous studies comparing microsites that are located beneath tree or shrub canopies and in openings have frequently shown improvement of topsoil fertility by the woody plants, creating a facilitation effect (e.g., GómezAparicio et al. 2005, Allegreza et al. 2016). Simard and Durall (2004) also observed that seedlings establishing near a tree canopy could benefit from the mycelial network that connects different communities of root symbionts. Seedlings could "plug in" to the existing network, thereby acquiring photosynthate and increasing nutrient uptake, compared with seedlings that are established in openings and isolated from such networks (e.g., Teste et al. 2009a,b). In the present study, positive correlations between seedling growth responses and various soil characteristics (K, CEC, TKN, P, LD, SIR, qMic and earthworms) indicated potential facilitative effects of mature oak trees on understory oak seedlings. Such positive effects on seedling survival and growth have already been observed in various environments (Simard and Durall 2004; Roberts et al. 2005; Closa and Goicoechea 2010; Lafleur et al. 2015).

\section{Conclusions and management recommendations}

Traditional management practices, specifically oak coppicing, produce small-scale heterogeneity of the forest floor, which can greatly influence seedling establishment success. This study emphasised the importance of a "canopy effect" that produces suitable environments for seedlings through the presence of a canopy cover. We have shown that this canopy effect is associated with favourable physical, chemical and biological soil conditions. In fact, litter accumulation beneath canopies increased soil nutrients, humidity and microbial activity in ways that were favourable to the establishment of large-seeded species such as Persian oak. Further research is needed to deepen our understanding of the interrelations between soil attributes and early seedling life-stages by taking into account predation and microclimatic conditions. However, this study demonstrates the importance of conserving the remaining large trees in degraded semi-arid, drought-prone environments and in forests disturbed by management activities. Remaining old trees promote the so-called "islands of 
fertility" by improving most of the soil parameters that represent suitable microhabitats for seedling recruitment. Our results suggest that tree facilitation has to be considered in management plans of Mediterranean woodlands, which are threatened by an insufficient density of mature trees, as has been observed in other Mediterranean forest ecosystems. We recommend the preservation of some forest patches from human disturbing activities (in particular wood cutting and grazing). These forest patches can be centred on groups of remnant trees as they represent suitable microhabitats for oak seedling recruitment. These old forest patches could also promote biodiversity and act as seed trees to help improve acorn dissemination and oak seedling establishment.

\section{Acknowledgements}

We thank S. Kocher for reviewing and making valuable comments on the manuscript and W.F.J. Parsons for English-language editing. Our work was partly supported by grants from the University of Ilam.

\section{References}

Abrams MD (2003) Where has all the white oak gone? BioScience 53: 927-939.

Alef Ž, Nannipieri KP (1995) Methods in Applied Soil Microbiology and Biochemistry. Academic Press, London. $576 \mathrm{pp}$.

Allegrezza M, Cort G, Cocco S, Pesaresi S, Chirico GB, Saracino A, Bonanomi G, 2016. Microclimate buffering and island formation during Juniperus communis ontogenesis modulate competition-facilitation balance. J Veg Sci 27: 616-627.

Amézquita MC, Ibrahim M, Llanderal T, Buurman P, Amézquita E (2005) Carbon sequestration in pastures, silvopastoral systems and forests in four regions of the Latin American tropics. J Sustainable For 21: 31-49.

Anderson JPE, Domsch KH (1978) Physiological method for quantitative measurement of microbial biomass in soils. Soil Biol Biochem 10: 215-221. 
Anderson TH, Domsch KH (1993) The metabolic quotient for $\mathrm{CO} 2\left(\mathrm{qCO}_{2}\right)$ as a specific activity parameter to assess the effects of environmental conditions such as $\mathrm{pH}$, on the microbial biomass of the soil. Soil Biol Biochem 25: 393-395.

Ashton MS, Larson BC (1996) Germination and seedling growth of Quercus (section Erythrobalanus) across openings in a mixed-deciduous forest of southern New England, USA. Forest Ecol Manag 80: 8194.

Augusto L, Dupouey JL, Ranger J (2003) Effects of tree species on understory vegetation and environmental conditions in temperate forests. Ann For Sci 60: 823-831.

Augusto L, Ranger J, Binkley D, Rothe A (2002) Impact of several common tree species of European temperate forests on soil fertility. Ann For Sci 59: 233-253.

Baskin CC, Baskin JM (1998) Seeds: Ecology, Biogeography, and Evolution of Dormancy and Germination. Academic Press, San Diego, CA.

Bernhardt EA, Swiecki TJ (1997) Effects of cultural inputs on survival and growth of direct seeded and naturally occurring valley oak seedlings on hardwood rangeland. pp. 301-311. In: Pillsbury NH, Verner J, Tietje WD (technical coordinators), Proceedings - Oak Woodlands: Ecology, Management, and Urban Interface Issues. USDA, Forest Service, Pacific Southwest Research Station, Albany, CA. General Technical Report PSW-GTR-160.

Black CA (1986) Methods of soil analysis, Part 1. ASA, Madison, WI, pp 545-566

Blake GR, Hartge KH (1986) Bulk density. pp. 363-376 In: Klute, A. (Ed.), Methods of Soil Analysis: Part I - Physical and Mineralogy Methods, $2^{\text {nd }}$ ed, Agronomy Monograph No. 9, American Society of Agronomy - Soil Science Society of America, Madison, WI.

Bobiec A, Jaszcz E, Wojtunik K (2011) Oak (Quercus robur L.) regeneration as a response to natural dynamics of stands in European hemiboreal zone. Eur J For Res 130: 785-797. 
Borken W, Savage K, Davidson EA, Trumbore SE (2006) Effects of experimental drought on soil respiration and radiocarbon efflux from a temperate forest soil. Global Change Biol 12: 177-193.

Bouché MB (1977) Strategies lombriciennes. pp. 122-132. In: Lohm U, Persson T (eds) Soil Organisms as Components of Ecosystems. Proceedings of the VI International Soil Zoology Colloquium, International Society of Soil Science (ISSS). Swedish Natural Science Research Council, Stockholm.

Bran D, Lobréaux O, Maistre M, Perret P, Romane, F (1990) Germination of Quercus ilex and Q. pubescens in a $Q$. ilex coppice: Long-term consequences. Vegetatio 87: 45-50.

Bray RH, Kurtz LT (1945) Determination of total organic and available forms of phosphorus in soils. Soil Sci 59: 39-45.

Bremner JM (1996) Nitrogen - Total. pp. 1085-1122. In: Sparks DL (Ed.), Methods of Soil Analysis: Part 3 - Chemical Methods. SSSA Book Series 5, Soil Science Society of America, Madison, WI.

Broncano MJ, Riba M, Retana J (1998) Seed germination and seedling performance of two Mediterranean tree species, Holm oak (Quercus ilex L.) and Aleppo pine (Pinus halepensis Mill.): a multifactor experimental approach. Plant Ecol 138: 17-26.

Brookes PC, Landman A, Pruden G, Jenkinson DS (1985) Chloroform fumigation and the release of soil nitrogen: A rapid direct extraction method to measure microbial biomass nitrogen in soil. Soil Biol Biochem 27: 167-172.

Brookes PC, Ocio JA, Wu J (1990) The microbial biomass, its measurement, properties and role in nitrogen and carbon dynamics following substrate incorporation. Soil Microorg 35: 39-51.

Bugalho MN, Caldeira MC, Pereira JS, Aronson J, Pausas JG (2011) Mediterranean cork oak savannas require human use to sustain biodiversity and ecosystem services. Front Ecol Environ 9: 278-286.

Bullock JM (2000) Gaps and seedling colonization. pp. 375-395. In: Fenner M (ed.). The Ecology of Regeneration of Plant Communities. CABI Publishing, Wallingford, UK. 
Caldeira MC, Ibáñez I, Nogueira C, Bugalho MN, Lecomte X, Moreira A, Pereira JS (2014) Direct and indirect effects of tree canopy facilitation in the recruitment of Mediterranean oaks. J Appl Ecol 51: 349358.

Camping TJ, Dagren, RA, Tate KW, Horwath WR (2002) Changes in soil quality due to grazing and oak tree removal in California blue oak woodlands. pp. 75-85 In: Standiford RB, McCreary D, Purcell KL (eds.), Oaks in California's Changing Landscape. USDA, Forest Service, Berkeley, CA. General Technical Report PSW-184.

Cisneros-Dozal LM, Trumbore S, Hanson PJ (2006) Partitioning sources of soil-respired $\mathrm{CO}_{2}$ and their seasonal variation using a unique radiocarbon tracer. Global Change Biol 12: 194-204.

Classen AT, Boyle SI, Haskins KE, Overby, ST, Hart SC (2003) Community-level physiological profiles of bacteria and fungi: plate type and incubation temperature influences on contrasting soils. FEMS Microbiol Ecol 44: 319-328.

Closa I, Goicoechea N (2010) Seasonal dynamics of the physicochemical and biological properties of soils in naturally regenerating, unmanaged and clear-cut beech stands in northern Spain. Eur J Soil Biol 46: 190199.

Costa A, Pereira H, Madeira M. 2010. Analysis of spatial patterns of oak decline in cork oak woodlands in Mediterranean conditions. Ann For Sci 67: 204. DOI: 10.1051/forest/2009097

Dahlgren RA, Horwath WR, Tate KW, Camping TJ (1997) Blue oak enhance soil quality in California oak woodlands. California Agriculture 57: 42-47.

Dahlgren RA, Singer MJ, Huang X (1997) Oak tree and grazing impacts on soil properties and nutrients in a California oak woodland. Biogeochemistry 39: 45-64.

Davenport DW, Wilcox BP, Breshears DD (1996) Soil morphology of canopy and intercanopy sites in a pinyon-juniper woodland. Soil Sci Soc Am J 60: 1881-1887. 
Delgado-Baquerizo M, Maestre FT, Gallardo A, Quero JL, Ochoa V, García-Gómez M, Escolar C, GarcíaPalacios P, Berdugo M, Valencia E, Gozalo B, Noumi Z, Derak M, Wallenstein, MD (2013) Aridity modulates $\mathrm{N}$ availability in arid and semiarid Mediterranean grasslands. PLoS ONE 8: e59807. DOI: 10.1371/journal.pone.0059807

Denman S, Brown N, Kirk S, Jeger M, Webber J (2014) A description of the symptoms of Acute Oak Decline in Britain and a comparative review on causes of similar disorders on oak in Europe. Forestry. doi: 10.1093/forestry/cpu010

de Martonne E (1925) Traité de géographie physique. 3 tomes, Paris.

Dey CD, Douglass J, McNabb K, Miller G, Baldwin V, Foster G (2008) Artificial regeneration of major oak (Quercus) species in the eastern United States - A review of the literature. For Sci 54: 77-106.

Dickie IA, Montgomery RA, Reich PB, Schnitzer SA (2007) Physiological and phenological responses of oak seedlings to oak forest soil in the absence of trees. Tree Physiol 27: 133-140.

Dilly O, Nannipieri P (1998) Intracellular and extracellular enzyme activity in soil with reference to elemental cycling. J Plant Nutr Soil Sci 161: 243-248.

Ebrahimzad SA, Aliasgharzad N, Najafi N (2013) Impressionability of some soil ecophysilogical [sic] indices by land use changes in Suldoz Plain (Naqadeh, West Azarbaijan [sic]). J Agric Prod Sci 23: 41-56. [in Farsi, with English summary]

Espelta JM, Bonal R, Sánchez-Humanes B (2009) Pre-dispersal acorn predation in mixed oak forests: Interspecific differences are driven by the interplay among seed phenology, seed size and predator size. $\mathrm{J}$ Ecol 97: 1416-1423.

Espelta JM, Riba M, Retana J (1995) Patterns of seedling recruitment in West-Mediterranean Quercus ilex forests influenced by canopy development. J Veg Sci 6: 465-472. 
Famiglietti J, Rudnicki J, Rodell M (1998) Variability in surface moisture content along a hill slope transect: Rattlesnake Hill, Texas. J Hydrol 210: 259-281.

Fan W, Guo H, Wang X, Duan R (2014) The effects of microhabitat, plant litter, and seed burial on the regeneration of Quercus wutaishanica and Pinus tabulaeformis. Scand J Forest Res 29: 183-192.

Franklin KA (2008) Shade avoidance. New Phytol 17: 930-944.

Fuchs MA, Krannitz PG, Harestad AS (2000) Factors affecting emergence and first year survival of seedlings of Garry oaks (Quercus garryana) in British Columbia, Canada. Forest Ecol Manag 137: 209219.

Ghazanfari H, Namiranian M, Sobhani H, Marvi Mohajer R (2004) Traditional forest management and its application to encourage public participation for sustainable forest management in the northern Zagros Mountains of Kurdistan Province, Iran. Scand J Forest Res 19: 65-71.

Gómez JM, García D, Zamora R (2003) Impact of vertebrate acorn- and seedling-predators on a Mediterranean Quercus pyrenaica forest. Forest Ecol Manag 180: 125-134.

Gómez-Aparicio L, Gómez JM, Zamora R, Boettinger JL (2005) Canopy vs. soil effects of shrubs facilitating tree seedlings in Mediterranean montane ecosystems. J Veg Sci 16: 191-198.

Gómez-Brandón M, Aira M, Lores M, Domínguez J (2011) Epigeic earthworms exert a bottleneck effect on microbial communities through gut associated processes. PLoS ONE 6(9): e24786. doi: 10.1371/journal.pone.0024786

Hailu T, Negash L, Olsson M (2002) Millettia ferruginea from southern Ethiopia: Impacts on soil fertility and growth of maize. Agroforest Syst 48:9-24.

Hannam KD, Quideau SA, Kishchuk BE, Oh SW, Wasylishen, RE (2005) Forest floor chemical properties are altered by clear-cutting in boreal mixed-wood forests stands dominated by trembling aspen and white spruce. Can J Forest Res 35: 2457-2468 
Hattori D, Kenzo T, Irino KO, Kendawang JJ, Ninomiya I, Sakurai, K (2013) Effects of soil compaction on the growth and mortality of planted dipterocarp seedlings in a logged-over tropical rainforest in Sarawak, Malaysia. Forest Ecol Manag 310: 770-776.

Helama S, Sohar K, Läänelaid A, Mäkelä HM, Raisio J (2016) Oak decline as illustrated through plantclimate interactions near the northern edge of species range. Bot Rev 82: 1-23. doi: 10.1007/ s12229-016$9160-3$

Heydari M, Poorbabaei H, Bazgir M, Salehi A, Eshaghirad J (2014) Earthworms as indicators for different forest management types and human disturbance in Ilam oak forest, Iran. Folia For Pol 56: 121-134.

Heydari M, Poorbabaei H, Salehi A, Esmaaelzade O (2013) Application of two-step clustering methods to investigate effects of oak forests conservative management of Ilam city on soil properties. Iranian J For Poplar Res 21: 329-343. [in Farsi, with English summary]

Howlett DS, Moreno G, Mosquera Losada MR, Nair PKR, Nair VD (2011) Soil carbon storage as influenced by tree cover in the dehesa cork oak silvopasture of central-western Spain. J Environ Monit 13: 1897-1904.

Ibáñez B, Gómez-Aparicio L, Stoll P, Ávila JM, Pérez-Ramos IM, Marañón T (2015) A neighborhood analysis of the consequences of Quercus suber decline for regeneration dynamics in Mediterranean forests. PLoS ONE 10: e0117827

Jahanbin R, Jahantab E, Alirezanezhad A, Javdani Z, Mirzaee MR (2013) The effects of shrubs common myrtle (Myrtus communis) on soil chemical and physical characteristics of Basht area. Ann Biol Res 4: $158-164$.

Jacobs AFG, Van Boxel JH, El-Kilani, RMM (1994) Nighttime free convection characteristics within a plant canopy. Boundary-Layer Meteor 71: 375-391. 
Jalali SGA, Ali-Arab AR, Tabari M, Akbarinia, M, Hosseini SM (2007) Effect of sowing depth on performance of Quercus castaneifolia seeding at different levels of canopy cover. Pak J Biol Sci 10: 10201027.

Jordan D, Ponder Jr F, Hubbard VC (2003) Effects of soil compaction, forest leaf litter and nitrogen fertilizer on two oak species and microbial activity. Appl Soil Ecol 23: 33-41.

Kabrick JM, Dey DC, Van Sambeek JW, Wallendorf M, Gold MA (2005) Soil properties and growth of swamp white oak and pin oak on bedded soils in the lower Missouri River floodplain. Forest Ecol Manag 204: $315-327$.

Kalra YP, Maynard DG (1991) Methods Manual for Forest Soil and Plant Analysis. Forestry Canada, Northwest Region, Northern Forestry Centre, Edmonton, AB. Information Report NOR-X-319E. 116 pp.

Khosravi S, Maleknia R, Khedrizadeh M (2016) Understanding the contribution of non-timber forest products to the livelihoods of forest dwellers in the Northern Zagos in Iran. Small-Scale Forestry. doi: $10.1007 / \mathrm{s} 12229-016-9160-3$

Knoepp JD, Coleman DC, Crossley Jr DA, Clark JS (2000) Biological indices of soil quality: an ecosystem case study of their use. Forest Ecol Manag 138: 357-368.

Kollmann J, Schill H-P (1996) Spatial patterns of dispersal, seed predation and germination during colonization of abandoned grassland by Quercus petraea and Corylus avellana. Vegetatio 125: 193-205.

Lafleur B, Cazal A, Leduc A, Bergeron Y (2015) Soil organic layer thickness influences the establishment and growth of trembling aspen (Populus tremuloides) in boreal forests. Forest Ecol Manag 347: 209-216.

Leiva MJ, Mancilla-Leyton JM, MartínVicente Á (2015) Differences in the facilitative ability of two Mediterranean shrubs on holm-oak seedling recruitment in Mediterranean savanna-forest ecosystems. Ecol Eng 82: 349-354. 
Leonardsson J, Löf M, Götmark F (2015) Exclosures can favour natural regeneration of oak after conservation-oriented thinning in mixed forests in Sweden: A 10-year study. Forest Ecol Manag 354: 1-9.

Li Q, Ma K (2003). Factors affecting establishment of Quercus liaotungensis Koidz. under mature mixed oak forest overstory and in shrubland. Forest Ecol Manag 176: 133-146.

Lindbladh M, Foster DR (2010). Dynamics of long-lived foundation species: the history of Quercus in southern Scandinavia. J Ecol 98: 1330-1345.

Loftis DL, McGee CE (ed.) (1993) Oak Regeneration: Serious Problems, Practical Recommendations (Symposium Proceedings). USDA, Forest Service, Southeastern Forest Experiment Station, Asheville, NC. General Technical Report SE-84. 319 pp.

MacDougall AS, Duwyn A, Jones NT (2010) Consumer-based limitations drive oak recruitment failure. Ecology 97: 2092-2099.

Marañón T (1988) Agro-sylvo-pastoral systems in the Iberian Peninsula: Dehesas and montados. Rangelands 10: 255-258.

Marshall VG (2000) Impacts of forest harvesting on biological processes in northern forest soils. Forest Ecol Manag 133: 43-60.

Matzner E, Ulrich B (1982) The turnover of protons by mineralization and ion uptake in a beech (Fagus sylvatica) and a Norway spruce ecosystem. pp. 93-103. In: Ulrich B, Pankrath J. (Eds.), Effects of Accumulation of Air Pollutants in Forest Ecosystems. D. Reidel Publishing Company, London.

McCarthy DR, Brown KJ (2006) Soil respiration responses to topography, canopy cover, and prescribed burning in an oak-hickory forest in southeastern Ohio. For Ecol Manag 237: 94-102.

McLean MA, Parkinson D (2000) Field evidence of the effects of the epigeic earthworm Dendrobaena octaedra on the microfungal community in pine forest floor. Soil Biol Biochem 32: 351-360. 
Mediavilla S, Escudero A (2010) Differences in biomass allocation patterns between saplings of two cooccurring Mediterranean oaks as reflecting different strategies in the use of light and water. Eur $\mathbf{J}$ For Res 129: 697-706.

Monnier Y, Prévosto B, Ripert C, Corbani C, Fernandez C (2012) Forest microhabitats influence seedling phenology of two co-existing Mediterranean oak species. J Veg Sci 23: 260-270.

Moreno G, Obrador JJ (2007) Effects of trees and understorey management on soil fertility and nutritional status of holm oaks in Spanish dehesas. Nutr Cycl Agroecosyst 78: 253-264.

Moreno G, Obrador JJ, García A (2007) Impact of evergreen oaks on soil fertility and crop production in intercropped dehesas. Agric Ecosyst Environ 119: 270-280.

Nambiar EKS, Sands R (1993) Competition for water and nutrients in forests. Can J For Res 23: 19551968.

Nelson DW, Sommers LE (1982) Total carbon, organic carbon and organic matter. pp. 961-1010. In: Page AL (Ed.). Methods of Soil Analysis: Part 3 - Chemical Methods. Book Series No. 5, Soil Science Society of America, Madison, WI.

Niinemets Ü, Valladares F (2004) Photosynthetic acclimation to simultaneous and interacting environmental stresses along natural light gradients: optimality and constraints. Plant Biol 6: 254-268.

Nolte DL, Barnett JP (2000) A repellent to reduce mouse damage to longleaf pine seed. Int J Biodeterior Biodegradation 45: 169-174.

Parkin TB, Berry EC (1999) Microbial nitrogen transformations in earthworm burrows. Soil Biol Biochem 31: 1765-1771. 
Pausas JG, Bladé C, Valdecantos A, Seva JP, Fuentes D, Alloza JA, Milagrosa A, Bautista S, Cortina J, Vallejo R (2004) Pine and oaks in the restoration of Mediterranean landscapes of Spain: New perspectives for an old practice - a review. Plant Ecol 171: 209-220.

Pedersen BS (1998) The role of stress in the mortality of midwestern oaks as indicated by growth prior to death. Ecology 79: 79-93.

Pereira JAA, Oliveira-Filho AT, Lemos-Filho JP (2007) Environmental heterogeneity and disturbance by humans control much of the tree species diversity of Atlantic montane forest fragments in SE Brazil. Plant Conserv Biodivers 16: 187-210.

Pérez-Ramos IM, Gómez-Aparicio L, Villar R, García LV, Marañón T (2010) Seedling growth and morphology of three oak species along field resource gradients and seed-mass variation: a seedling-agedependent response. J Veg Sci 21: 419-437.

Pignataro A, Moscatelli MC, Mocali S, Grego S, Benedetti A (2012) Assessment of soil microbial functional diversity in a coppiced forest system. Appl Soil Ecol 62: 115-123.

Pourhashemi M, Zande Basiri M, Panahi P (2012) Evaluation of visual surveys to estimate acorn production of Gall oak (Quercus infectoria Olivier) in Baneh. Iranian J For Poplar Res 20: 243-254. [in Farsi with English summary]

Pourreza M, Hosseini SM, Safari Sinegani AA, Matinizadeh, M, Dick WA (2014) Soil microbial activity in response to fire severity in Zagros oak (Quercus brantii Lindl.) forests, Iran, after one year. Geoderma 213: 95-102.

Puerta-Piñero C, Gómez JM, Valladares F (2007) Irradiance and oak seedling survival and growth in a heterogeneous environment. Forest Ecol Manag 242: 462-469.

Pyttel PL, Köhn M, Bauhus J (2015) Effects of different harvesting intensities on the macro nutrient pools in aged oak coppice forests. Forest Ecol Manag 349: 94-105. 
Quero JL, Villar R, Marañón T, Zamora R, Poorter L (2007) Seed-mass effects in four Mediterranean Quercus species (Fagaceae) growing in contrasting light environments. American Journal of Botany 94(11): 1795-1803.

Ragazzi A, Vagniluca S, Moricca S, Vigniluca S (1995) European expansion of oak decline: involved microorganisms and methodological approaches. Phytopathologia Mediterranea 34: 207-226.

Ramirez-Valiente JA, Sanchez-Gomez D, Gil L, Aranda I, Valladares F (2009) Population differences in juvenile survival under increasing drought are mediated by seed size in cork oak (Quercus suber L.). Forest Ecol Manag 257: 1676-1683.

Ramos-Palacios CR, Badano EI, Flores J, Flores-Cano JA, Flores-Flores JL (2014) Distribution patterns of acorns after primary dispersion in a fragmented oak forest and their consequences on predators and dispersers. Eur J For Res 133: 391-404.

Rawnsley B (2008) Implications of strategic irrigation management practices for vine root health. Final report to the Grape and Wine Research and Development Corporation, Project SAR 03/04 (SARDI: Adelaide, SA, Australia). pp. 36-48.

Reichstein M, Tenhunen JD, Roupsard O, Ourcival J-M, Rambal S, Dore S, Valentini R (2002) Ecosystem respiration in two Mediterranean evergreen Holm Oak forests: drought effects and decomposition dynamics. Funct Ecol 16: 27-39.

Rencher AC (2003) Methods of Multivariate Analysis, $2^{\text {nd }}$ ed. Wiley, New York, NY.

Roberts SD, Harrington CA, Terry TA (2005) Harvest residue and competing vegetation affect soil moisture, soil temperature, N availability, and Douglas-fir seedling growth. Forest Ecol Manag 205: 333350.

Rodewald AD (2003) Decline of oak forests and implications for forest wildlife conservation. Nat Area J 23: $368-371$. 
Rodríguez-Calcerrada J, Cano FJ, Valbuena-Carabaña M, Gil L, Aranda I (2010) Functional performance of oak seedlings naturally regenerated across microhabitats of distinct overstorey canopy closure. New Forests 39: $245-259$.

Rodríguez-Calcerrada J, Nanos N, del Rey MC, Lopez de Heredia U, Escribano R, Gil L (2011) Small-scale variation of vegetation in a mixed forest understorey is partly controlled by the effect of overstory composition on litter accumulation. J For Res 16: 473-483.

Rodriguez-Estevez V, Sanchez-Rodriguez, Arce C, Garcia AR, Perea JM, Gomez-Castro G (2012) Consumption of acorns by finishing Iberian pigs and their function in the conservation of the dehesa agroecosystem. In Kaonga M (ed.), Agroforestry for Biodiversity and Ecosystem Services - Science and Practice. InTech ISBN: 978-953-51-0493-3.

Rolo V, Plieninger T, Moreno G J (2013) Facilitation of holm oak recruitment through two contrasted shrub species in Mediterranean grazed woodlands. J Veg Sci 24: 344-355.

Ryan MG, Law BE (2005) Interpreting, measuring, and modeling soil respiration. Biogeochemistry 73: 327.

Saetre P (1998) Decomposition, microbial community structure, and earthworm effects along a birchspruce soil gradient. Ecology 79: 834-846.

Sagheb-Talebi K, Sajedi F, Yazdian T (2004) Forests of Iran. Research Institute of Forests and Rangelands, Tehran, No. 339. [in Farsi with English summary]

Salehi A, Ghorbanzadeh N, Kahneh E (2013) Earthworm biomass and abundance, soil chemical and physical properties under different poplar plantations in the north of Iran. J For Sci 56: 223-229.

Salehi A, Karltun LCh, Söderberg U, Eriksson LO (2010) Livelihood dependency on woodland resources in southern Zagros, Iran. Caspian J Env Sci 8: 181-194. 
Sayer E (2006) Using experimental manipulation to assess the roles of leaf litter in the functioning of forest ecosystems. Biol Rev 81: 1-31.

Schade JD, Hobbie SE (2005) Spatial and temporal variation in islands of fertility in the Sonoran Desert. Biogeochemistry 73: 541-553.

Schädler M, Brandl R (2005) Do invertebrate decomposers affect the disappearance rate of litter mixtures? Soil Biol Biochem 37: 329-337.

Schlesinger WH, Raikes JA, Hartley AE, Cross AF (1996) On the spatial pattern of soil nutrients in desert ecosystems. Ecology 77: 364-374.

Schlesinger WH, Reynolds JF, Cunningham GL, Huenneke LF, Jarell WM, Virginia RA, Whitford WG (1990) Biological feedbacks in global desertification. Science 247: 1043-1048.

Schuur EAG, Trumbore SE (2006) Partitioning sources of soil respiration in boreal black spruce forest using radiocarbon. Global Change Biol 12: 165-176.

Sellin A, Ounapuu E, Karusion A (2010) Experimental evidence supporting the concept of light-mediated modulation of stem hydraulic conductance. Tree Physiol 30:1528-1535.

Selosse M-A, Richard F, He X, Simard SW (2006) Mycorrhizal networks: des liaisons dangereuses? Trends Ecol Evol 61: 621-628.

Seymour G, Tecle A (2004) Impact of slash pile size and burning on ponderosa pine forest soil physical properties. J Arizona-Nevada Acad Sci 37: 74-82.

Shankar U (2006) Seed size as a predictor of germination success and early seedling growth in "Hollong" (Dipterocarpus macrocarpus Vesque). New Forests 31: 305-320.

Shukla MK Lal R, Ebinger M, Meyer C (2006) Physical and chemical properties of soils under some piñonjuniper-oak canopies in a semi-arid ecosystem in New Mexico. J Arid Environ 66: 673-685. 
Shvaleva A, Costa e Silva F, Costa JM, Correia A, Anderson M, Lobo-do-Vale R, Fangueiro D, Bicho C, Pereira JS, Chaves MM, Skiba U, Cruz C (2014) Comparison of methane, nitrous oxide fluxes and CO2 respiration rates from a Mediterranean cork oak ecosystem and improved pasture. Plant Soil 374: 883-898.

Simard SW, Durall DM (2004) Mycorrhizal networks: a review of their extent, function, and importance. Can J Bot 82: 1140-1165.

Simón N, Montes F, Díaz-Pinés E, Benavides R, Roig S, Rubio A (2013) Spatial distribution of the soil organic carbon pool in a Holm oak Dehesa in Spain. Plant Soil 366: 537-549.

Soil Survey Staff (2014) Keys to Soil Taxonomy, 12th ed. USDA-Natural Resources Conservation Service, Washington, DC.

Sparling GP (1992) Ratio of microbial biomass carbon to soil organic carbon as a sensitive indicator of changes in soil organic matter. Aust J Soil Res 30: 195-207.

Sparling G, Vojvodic-Vukovic M, Schipper LA (1998) Hot-water-soluble C as a simple measure of labile soil organic matter: the relationship with microbial biomass C. Soil Biol Biochem 30: 1469-1472.

Steinkamp J, Hickler T (2015. Is drought-induced forest dieback globally increasing? J Ecol 103: 44-57.

Strandberg B, Kristiansen SM, Tybirk K (2005) Dynamic oak-scrub to forest succession: effects of management on understorey vegetation, humus forms and soils. Forest Ecol Manag 211: 318-328.

Strobel BW, Bernhoft I, Borgaard OK (1999) Low-molecular-weight aliphatic carboxylic acids in soil solutions under different vegetations determined by capillary zone electrophoresis. Plant Soil 212: 115-121. Sumner ME, Miller WP (1996) Cation exchange capacity and exchange coefficients. pp. 1085-1122. In D.L. Sparks (ed.) Methods of Soil Analysis: Part 3 - Chemical Properties. SSSA Book Series 5, Soil Science Society of America, Madison, WI.

Tate KW, Dudley DM, McDougald NK, George MR (2004) Effect of canopy and grazing on soil bulk density. J Range Manage 57: 411-417. 
Tedeschi V, Rey A, Manca G, Valentini R, Jarvis PG, Borghetti, M (2006) Soil respiration in a Mediterranean oak forest at different developmental stages after coppicing. Global Change Biol 12: 110121.

Teste FP, Simard SW, Durall DM (2009) Role of mycorrhizal networks and tree proximity in ectomycorrhizal colonization of planted seedlings. Fungal Ecol: 21-30.

Teste FP, Simard SW, Durall DM, Guy RD, Jones MD, Schoonmaker AL (2009) Access to mycorrhizal networks and tree roots: importance for seedling survival \& resource transfer Ecology, 90: 2808-2822.

Thomas FM, Blank R, Hartmann G (2002) Abiotic and biotic factors and their interactions as causes of oak decline in Central Europe. Forest Pathol 32: 277-307.

Tietje WD, Nieves SN, Honig JA, Weitkamp WH (1991) Effect of acorn planting depth on depredation, emergence, and survival of valley and blue oak. pp. 14-20. In: Standiford RB (technical coordinator), Proceedings - Symposium on Oak Woodlands and Hardwood Rangeland Management. USDA, Forest Service, Pacific Southwest Research Station, Berkeley, CA. Gen Technical Report PSW-GTR-126.

Tomašić M, Zgorelec T, Jurišić A, Kisić I (2013) Cation exchange capacity of dominant soil types in the Republic of Croatia. J Cent Eur Agric14: 937-951.

Truax B, Lambert F, Gagnon D (2000) Herbicide-free plantations of oaks and ashes along a gradient of open to forested mesic environments. Forest Ecol Manag 137: 155-169.

Tsakaldimi M, Tsitsoni T, Ganatas P, Zagas T (2009) A comparison of root architecture and shoot morphology between naturally regenerated and container-grown seedlings of Quercus ilex. Plant Soil 324: $103-113$.

Valipour A, Plieninger T, Shakeri Z, Ghazanfari H, Namiranian M, Lexer MJ (2014). Traditional silvopastoral management and its effects on forest stand structure in northern Zagros, Iran. Forest Ecol Manag 327: 221-230. 
Vance ED, Brookes PD, Jenkinson DS (1987) An extraction method for determining soil microbial biomass C. Soil Biol Biochem 19: 703-707.

Whitford WG, Anderson J, Rice PM (1997) Stemflow contribution to the 'fertile island' effect in creosotebush, Larrea tridentata. J Arid Environ 35: 451-457.

Woods K, Elliott S (2004) Direct seeding for forest restoration on abandoned agricultural land in Northern Thailand. J Trop For Sci 16: 248-259.

Zeng DH, Hu YL, Chang SX, Fan ZP (2009) Land cover change effects on soil chemical and biological properties after planting Mongolian pine (Pinus sylvestris var. mongolica) in sandy lands in Keerqin, northeastern China. Plant Soil 317: 121-133. 
Author-produced version of the article published in European Journal of Forest Research, 136, 2, 2017, 287-305. The original publication is available at https://link.springer.com/article/10.1007/s10342-017-1029-4

DOI: $10.1007 / \mathrm{s} 10342-017-1029-4$

Table 1. Main mensurational characteristics (mean $\pm \mathrm{SE}$ ) of Quercus brantii within four microhabitats. Ten clumps/ trees per type were used for measurements.

\begin{tabular}{lcccc}
\hline Microhabitats & $\begin{array}{c}\text { DBH } \\
(\mathbf{c m})\end{array}$ & $\begin{array}{c}\text { Height } \\
(\mathbf{m})\end{array}$ & $\begin{array}{c}\text { Number of sprouts per } \\
\text { clump }\end{array}$ & $\begin{array}{c}\text { Crown canopy area } \\
\left(\mathbf{m}^{\mathbf{2}}\right)\end{array}$ \\
\hline UCTT & $64.00 \pm 4.42$ & $7.20 \pm 0.60$ & - & $38.00 \pm 2.81$ \\
ISPC & $26.21 \pm 3.79$ & $4.20 \pm 0.34$ & $5.11 \pm 0.50$ & $26.14 \pm 2.20$ \\
RSC & $2.17 \pm 0.09$ & $1.30 \pm 0.12$ & $6.10 \pm 0.37$ & $2.21 \pm 0.09$ \\
OCTS & - & - & - & - \\
\hline
\end{tabular}

Abbreviations: under the canopy of tall trees (UCTT), inside old sprout clumps (ISPC), outside the canopy of high trees and sprout clumps (OCTS), and recent stumps or sprout clumps (RSC), DBH diameter at breast height.

Table 2. Soil physical and chemical variables (mean \pm SE) measured in the different microhabitats

\begin{tabular}{|c|c|c|c|c|}
\hline Physical-chemical variables & UCTT & ISPC & OCTS & RSC \\
\hline SOC (g/kg dry soil) & $58.01 \pm 1.24 \mathrm{a}$ & $41.06 \pm 1.11 \mathrm{~b}$ & $29.18 \pm 0.82 \mathrm{c}$ & $30.15 \pm 0.91 \mathrm{c}$ \\
\hline $\mathbf{p H}$ & $7.11 \pm 0.05 b$ & $7.20 \pm 0.05 b$ & $7.50 \pm 0.01 \mathrm{a}$ & $7.40 \pm 0.01 \mathrm{a}$ \\
\hline EC $(d S / m)$ & $0.51 \pm 0.02 \mathrm{a}$ & $0.44 \pm 0.02 b$ & $0.31 \pm 0.03 \mathrm{c}$ & $0.33 \pm 0.03 \mathrm{c}$ \\
\hline $\mathrm{CEC}\left(\mathrm{cmol}^{+} / \mathrm{kg}\right)$ & $32.21 \pm 2.41 \mathrm{a}$ & $26.69 \pm 2.28 b$ & $23.32 \pm 1.18 \mathrm{c}$ & $22.71 \pm 1.17 \mathrm{c}$ \\
\hline TKN (g/kg dry soil) & $4.96 \pm 0.14 \mathrm{a}$ & $3.63 \pm 0.28 b$ & $2.34 \pm 0.11 \mathrm{c}$ & $2.43 \pm 0.11 \mathrm{c}$ \\
\hline Available P (mg/kg dry soil) & $35.11 \pm 1.21 \mathrm{a}$ & $29.21 \pm 0.83 b$ & $18.13 \pm 0.61 \mathrm{c}$ & $17.22 \pm 0.39 \mathrm{c}$ \\
\hline Available K (mg/kg dry soil) & $520.18 \pm 18.22 \mathrm{a}$ & $452.23 \pm 16.24 b$ & $321.21 \pm 15.82 \mathrm{c}$ & $337.17 \pm 12.21 \mathrm{c}$ \\
\hline Water content $(\%)$ & $33.14 \pm 0.71 \mathrm{a}$ & $23.44 \pm 0.34 \mathrm{~b}$ & $15.33 \pm 0.21 \mathrm{c}$ & $20.12 \pm 0.29 b$ \\
\hline Bulk density $\left(\mathrm{g} / \mathrm{cm}^{3}\right)$ & $0.89 \pm 0.02 \mathrm{c}$ & $1.12 \pm 0.04 \mathrm{~b}$ & $1.21 \pm 0.06 \mathrm{a}$ & $1.26 \pm 0.02 \mathrm{a}$ \\
\hline Clay $(\%)$ & $27.00 \pm 1.23 \mathrm{a}$ & $25.05 \pm 0.89 b$ & $24.43 \pm 1.02 \mathrm{~b}$ & $24.69 \pm 0.86 b$ \\
\hline Silt $(\%)$ & $25.00 \pm 0.76$ & $26.18 \pm 1.13$ & $25.70 \pm 0.95$ & $26.19 \pm 0.65$ \\
\hline Sand $(\%)$ & $48.00 \pm 1.53$ & $48.77 \pm 1.45$ & $49.87 \pm 1.60$ & $49.12 \pm 1.75$ \\
\hline Litter depth (cm) & $15.12 \pm 1.32 \mathrm{a}$ & $11.14 \pm 1.21 \mathrm{~b}$ & $8.05 \pm 0.92 c$ & $5.03 \pm 0.83 \mathrm{~d}$ \\
\hline
\end{tabular}

Within rows, means with the same letters do not significantly differ $(P<0.05)$. Abbreviations: under the canopy of tall trees (UCTT),

inside old sprout clumps (ISPC), outside the canopy of high trees and sprout clumps (OCTS), and recent stumps or sprout clumps

(RSC); EC, electrical conductivity; CEC, cation exchange capacity; SOC, soil organic carbon; TKN, total Kjeldahl nitrogen 
DOI: $10.1007 / \mathrm{s} 10342-017-1029-4$

Table 3. Soil microbial variables (mean \pm SE) of soil measured in the different microhabitats

\begin{tabular}{|c|c|c|c|c|}
\hline Soil biological variables & UCTT & ISPC & OCTS & RSC \\
\hline $\mathrm{MBC}(\mu g / g)$ & $1044.12 \pm 22.01 \mathrm{a}$ & $863.18 \pm 19.01 b$ & $428.81 \pm 8.08 \mathrm{c}$ & $371.74 \pm 8.32 \mathrm{c}$ \\
\hline $\mathrm{MBN}(\mu g / g)$ & $81.14 \pm 5.30 \mathrm{a}$ & $69.93 \pm 4.11 b$ & $37.84 \pm 3.06 \mathrm{c}$ & $28.61 \pm 2.28 \mathrm{c}$ \\
\hline $\mathrm{BR}\left(\mathrm{mg} \mathrm{CO} \mathrm{C}_{2}-\mathrm{C} / \mathrm{kg} / \mathrm{day}\right)$ & $16.24 \pm 1.84 \mathrm{a}$ & $11.54 \pm 1.13 b$ & $7.51 \pm 0.82 \mathrm{c}$ & $6.41 \pm 0.71 \mathrm{c}$ \\
\hline qMic (mg MBC/g C soil) & $2.11 \pm 0.11 \mathrm{a}$ & $1.80 \pm 0.14 \mathrm{~b}$ & $1.60 \pm 0.21 \mathrm{c}$ & $1.13 \pm 0.18 \mathrm{~d}$ \\
\hline $\mathrm{qCO}_{2}(\mathrm{mg} \mathrm{CO}-\mathrm{C} / \mathrm{mg} / \mathrm{MBC})$ & $15.50 \pm 1.21 \mathrm{~b}$ & $13.32 \pm 1.21 \mathrm{c}$ & $17.51 \pm 1.40 \mathrm{a}$ & $17.31 \pm 1.41 \mathrm{a}$ \\
\hline $\mathrm{SIR}$ (mg CO${ }_{2}-\mathrm{C} / \mathrm{kg} \mathrm{soil} /$ day & $26.11 \pm 1.6 \mathrm{a}$ & $21.50 \pm 0.90 b$ & $10.72 \pm 0.71 \mathrm{c}$ & $9.31 \pm 0.50 \mathrm{c}$ \\
\hline Earthworms (Number $/ \mathrm{m}^{2}$ & $5.14 \pm 0.02 \mathrm{a}$ & $3.94 \pm 0.04 b$ & $2.18 \pm 0.06 \mathrm{c}$ & $1.92 \pm 0.02 \mathrm{c}$ \\
\hline
\end{tabular}

inside old sprout clumps (ISPC), outside the canopy of high trees and sprout clumps (OCTS), and recent stumps or sprout clumps

(RSC); MBC, Microbial Biomass Carbon; MBN, Microbial Biomass Nitrogen; BR, Basal Respiration; qMic, Microbial quotient; $\mathrm{qCO}_{2}$, Metabolic coefficient; SIR, substrate-induced respiration 
Author-produced version of the article published in European Journal of Forest Research, 136, 2, 2017, 287-305. The original publication is available at https://link.springer.com/article/10.1007/s10342-017-1029-4

DOI: $10.1007 / \mathrm{s} 10342-017-1029-4$

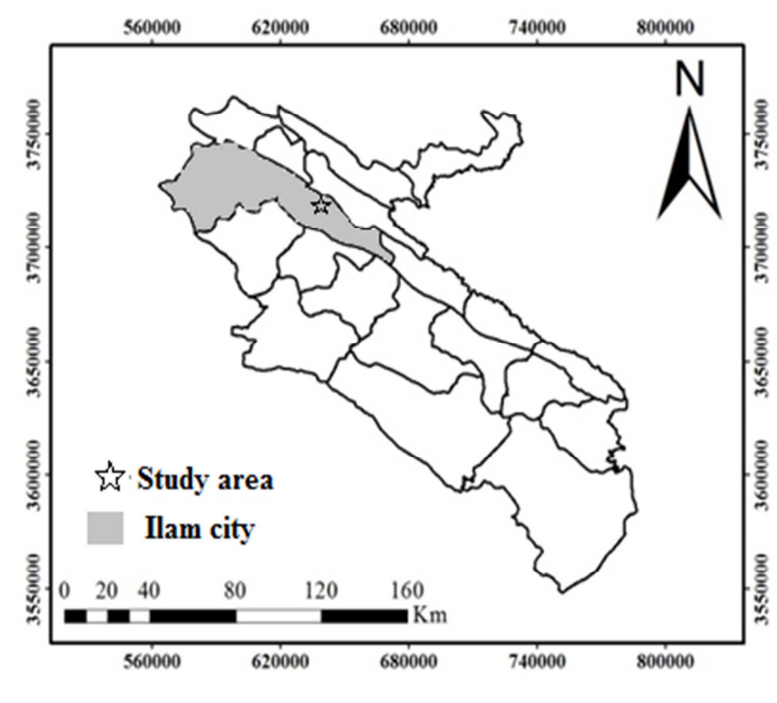

Ilam province

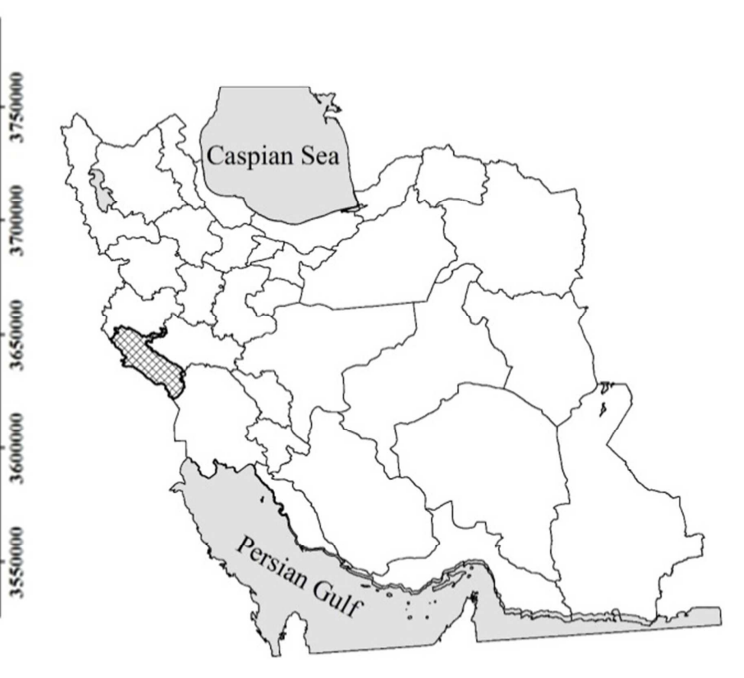

Iran

Fig. 1 The study area location in Iran and Ilam city 
Author-produced version of the article published in European Journal of Forest Research, 136, 2, 2017, 287-305. The original publication is available at https://link.springer.com/article/10.1007/s10342-017-1029-4

DOI: 10.1007/s10342-017-1029-4

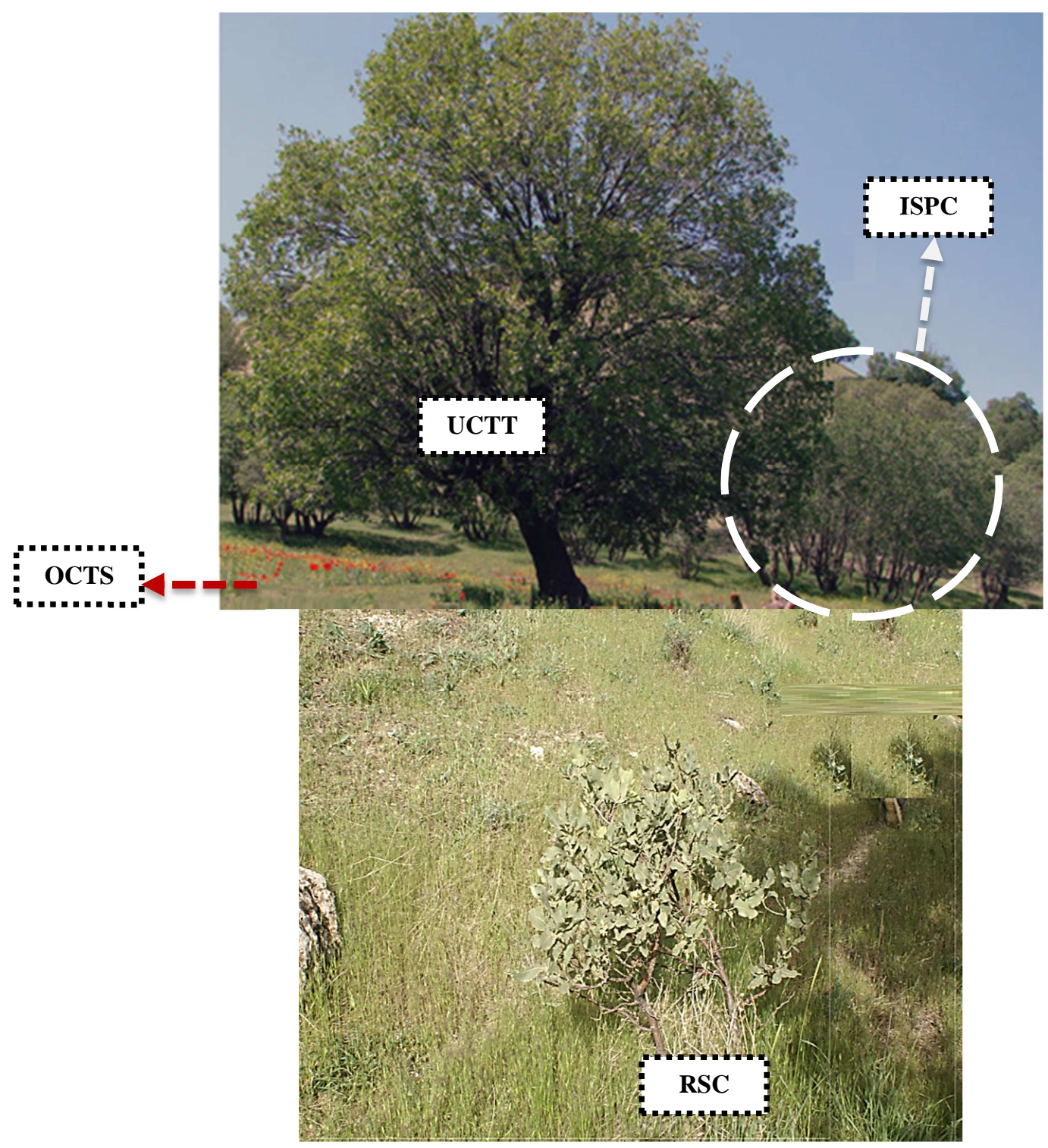

Fig. 2 Microhabitats areas, under the canopy of high trees (UCTT), inside old sprout clumps (ISPC), outside the canopy of high trees and sprout clumps (OCTS) and recent stumps or sprout clumps (RSC). 
Author-produced version of the article published in European Journal of Forest Research, 136, 2, 2017, 287-305.

The original publication is available at https://link.springer.com/article/10.1007/s10342-017-1029-4

DOI: $10.1007 / \mathrm{s} 10342-017-1029-4$

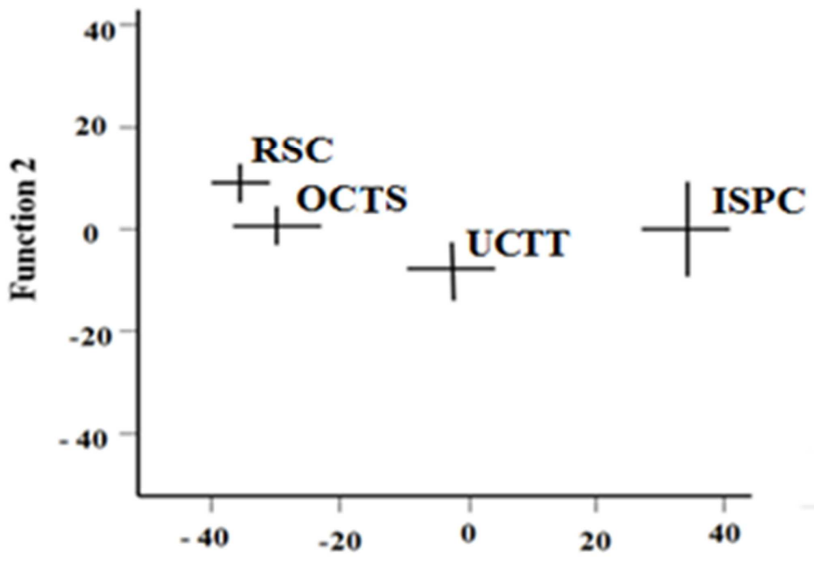

Function 1

Fig. 3 Scatter plot of the first two discriminant function values for each microhabitat (mean and standard deviation bar), under the canopy of high trees (UCTT), inside old sprout clumps (ISPC), outside the canopy of high trees and sprout clumps (OCTS) and recent stumps or sprout clumps (RSC).
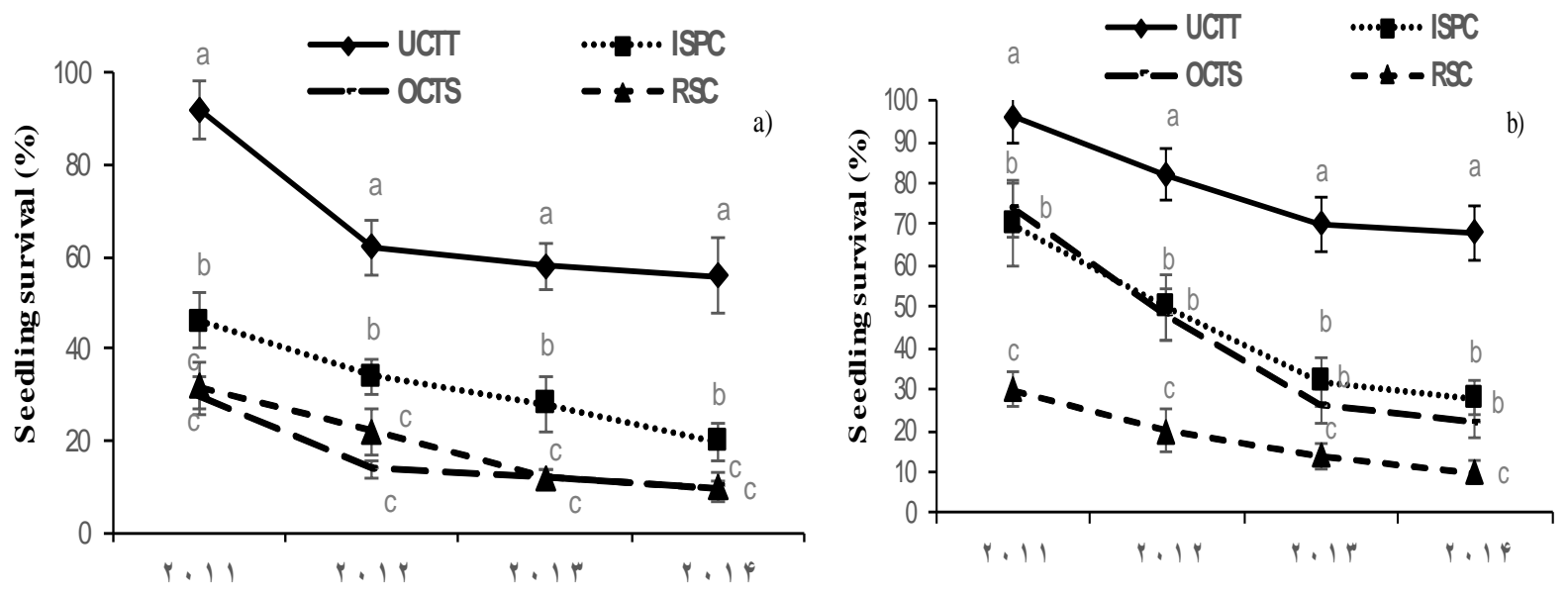

Fig. 4 Changes of seedling survival (mean $\pm \mathrm{SE}$ ) with years according to the different microhabitats (UCTT, ISPC, RSC and OCTS) at seeding depth $2 \mathrm{~cm}$ (a) and $5 \mathrm{~cm}$ (b). Means with the same letters are not significantly different between microhabitats for a same year based on Duncan's multiple range test ( $\mathrm{p}<0.01$ ). Abbreviations: under the canopy of high trees (UCTT), inside old sprout clumps (ISPC), outside the canopy of high trees and sprout clumps (OCTS) and recent stumps or sprout clumps (RSC). 
Author-produced version of the article published in European Journal of Forest Research, 136, 2, 2017, 287-305. The original publication is available at https://link.springer.com/article/10.1007/s10342-017-1029-4

DOI: $10.1007 / \mathrm{s} 10342-017-1029-4$

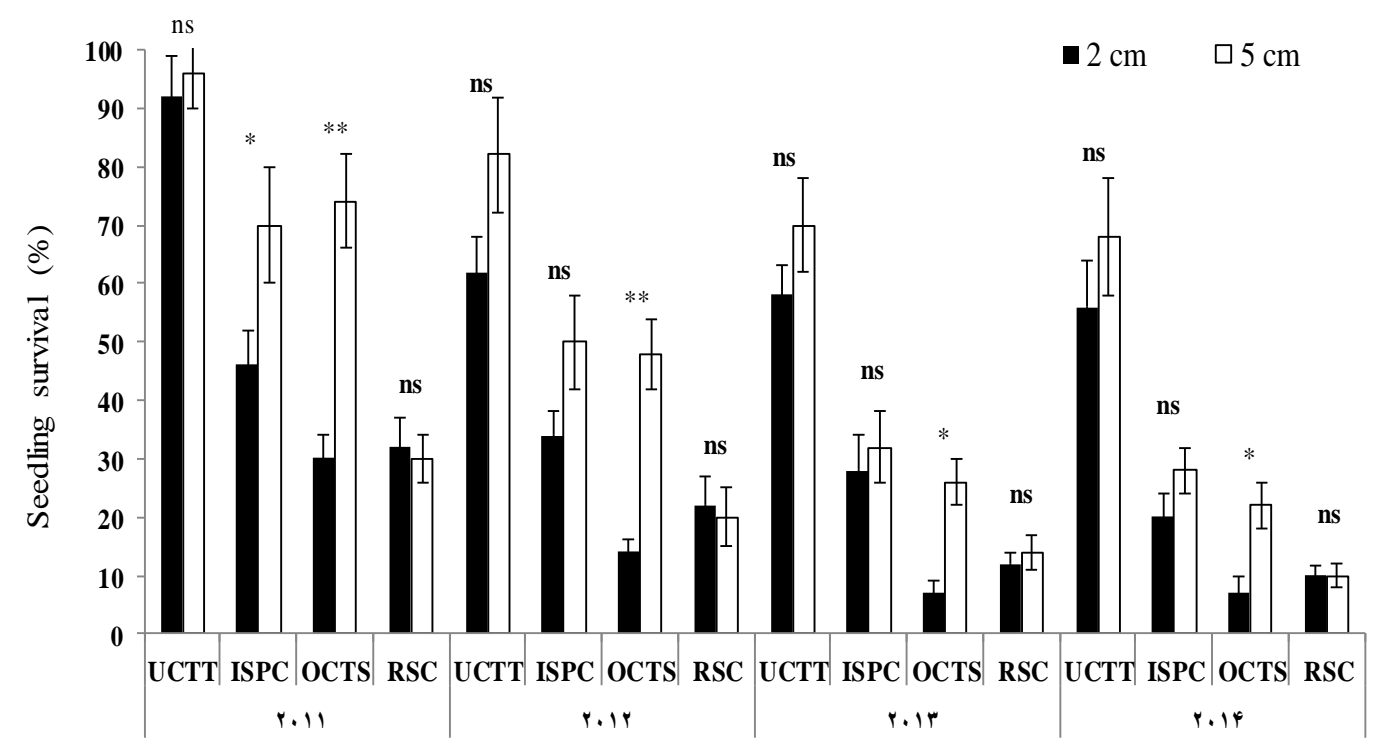

Fig. 5 Differences in seedling survival (mean \pm SE) between the two soil depths for each microhabitat and each year.

Stars indicate significant differences $(* \mathrm{p}<0.05$ and $* * p<0.01)$ between the two seeding depths in each microhabitat and in each year based on independent $\mathrm{t}$-test. $\mathrm{ns}=$ not significant $(\mathrm{p} \geq 0.05)$
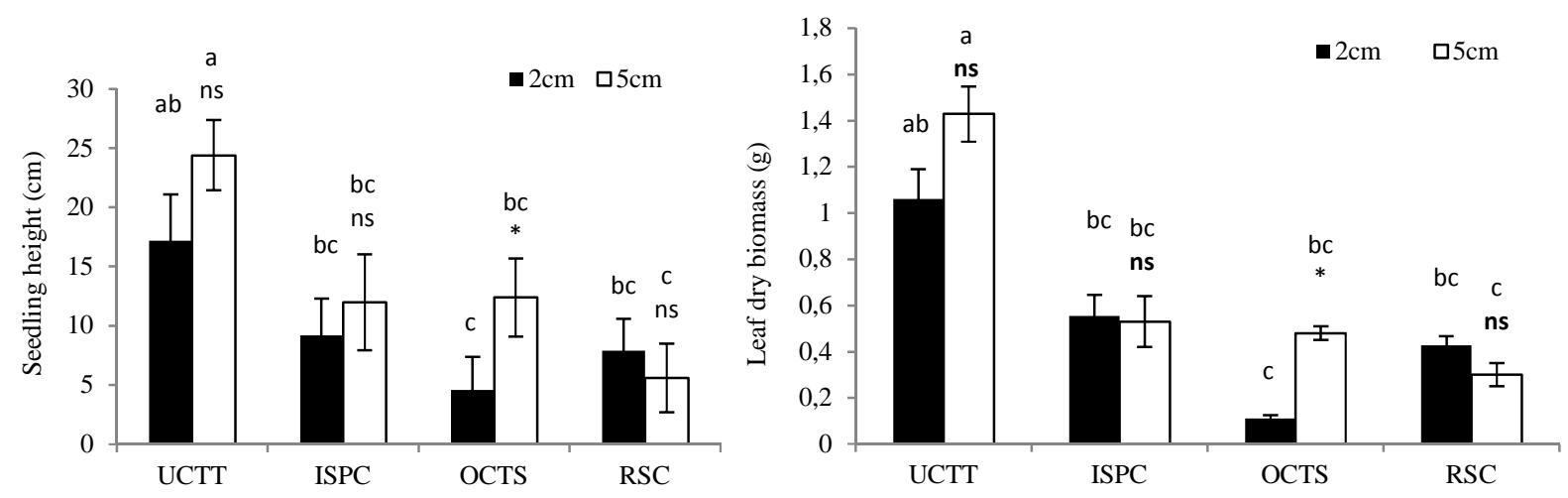

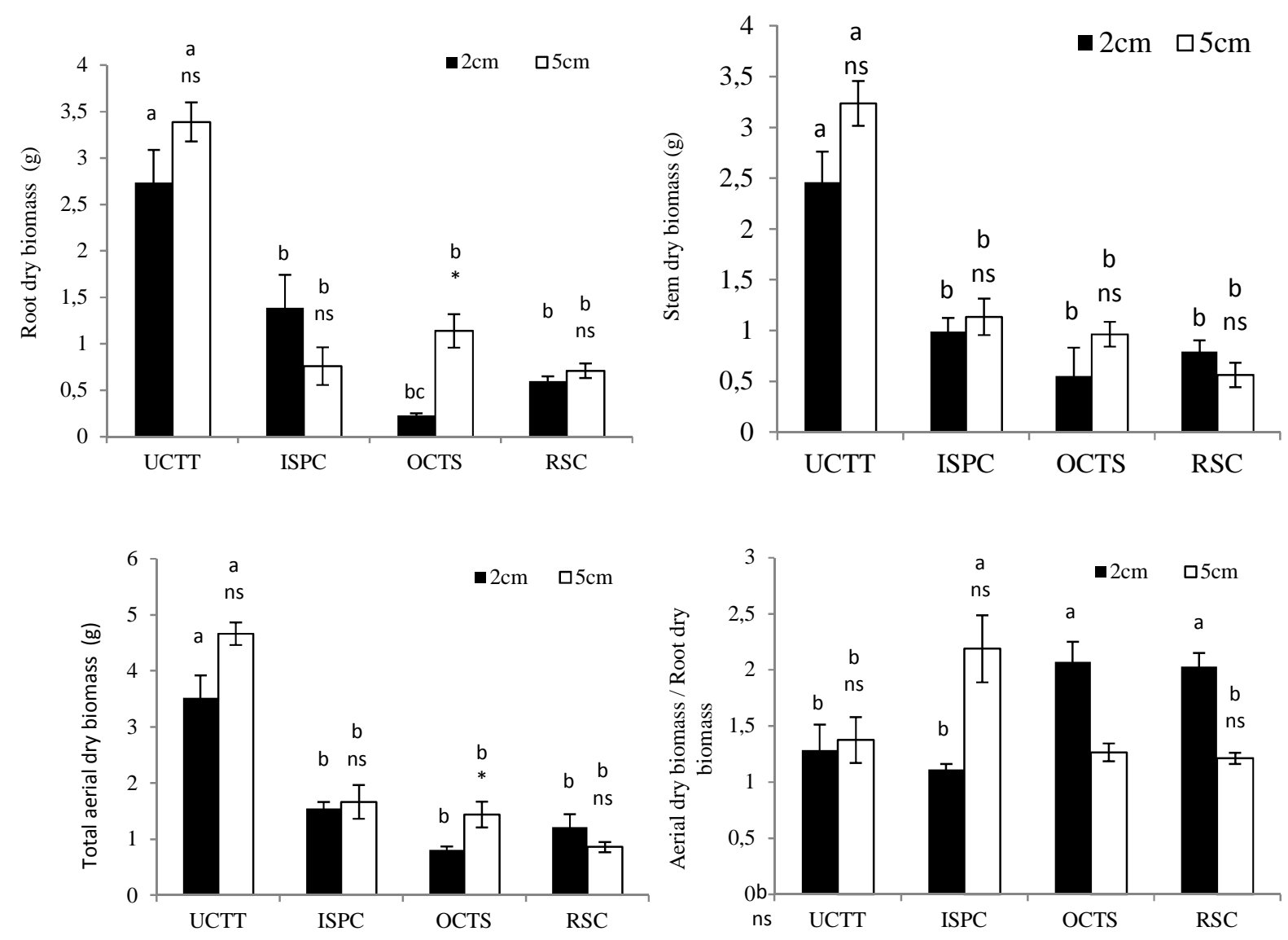
Author-produced version of the article published in European Journal of Forest Research, 136, 2, 2017, 287-305. The original publication is available at https://link.springer.com/article/10.1007/s10342-017-1029-4

DOI: $10.1007 / \mathrm{s} 10342-017-1029-4$

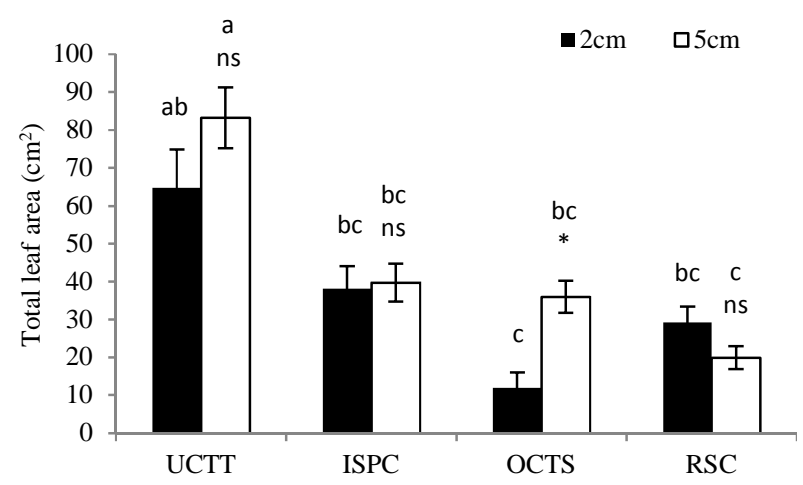

Fig. 6 Differences in seedling height, total leaf area, leaf dry biomass, root dry biomass, stem dry biomass, total aerial dry biomass and aerial dry biomass / root dry biomass (mean \pm standard error) according to the different microhabitats (UCTT, ISPC, OCTS and RSC) and seeding depths $(2$ and $5 \mathrm{~cm}$ ) in the fourth year after seeding. Letters indicate significant differences between microhabitats for a same sowing depth based on Duncan's multiple range test $(\mathrm{p}<0.01)$. Stars indicate significant differences between the two seeding depths in each microhabitat based on independent t-test $\left(* \mathrm{p}<0.05,{ }^{* *} \mathrm{p}<0.01\right.$, ns: not significant $\left.\mathrm{p} \geq 0.05\right)$. 